\title{
Effects of dietary soyabean meal, inulin and oxytetracycline on intestinal microbiota and epithelial cell stress, apoptosis and proliferation in the teleost Atlantic salmon (Salmo salar L.)
}

\author{
Anne Marie Bakke-McKellep ${ }^{1,2}$, Michael H. Penn ${ }^{1,2,3}$, Patricia Mora Salas ${ }^{1,2,4}$, Ståle Refstie ${ }^{1,5}$, \\ Sigmund Sperstad ${ }^{6}$, Thor Landsverk ${ }^{1,2}$, Einar Ring $\emptyset^{1,2}$ and Åshild Krogdahl ${ }^{1,2}$ \\ ${ }^{1}$ Aquaculture Protein Centre, CoE, Norway \\ ${ }^{2}$ Norwegian School of Veterinary Science, P.O. Box 8146 Dep., N-0033 Oslo, Norway \\ ${ }^{3}$ School of Natural Resources, The Ohio State University, Columbus, OH 43210, USA \\ ${ }^{4}$ Diagnotec S.A., Sargento Aldea 2650, Puerto Montt, Chile \\ ${ }^{5}$ Institute of Aquaculture Research (AKVAFORSK), N-6600, Sunndals $\phi$ ra, Norway \\ ${ }^{6}$ Norwegian College of Fishery Science, University of Troms $\phi$, N-9037 Troms $\phi$, Norway
}

(Received 10 May 2006 - Revised 4 October 2006 - Accepted 10 October 2006)

\begin{abstract}
Soyabean meal (SBM)-induced enteritis in the distal intestine of the teleost Atlantic salmon (Salmo salar L.) and other salmonids may be considered a model for diet-related mucosal disorders in other animals and man. The role of the intestinal microbiota in its pathogenesis was explored. Compared to diets containing fishmeal (FM) as the sole protein source, responses to extracted SBM or the prebiotic inulin, with or without oxytetracycline (OTC) inclusion, were studied following a 3-week feeding trial. Intestinal microbiota, organosomatic indices and histology, as well as immunohistochemical detection of proliferating cell nuclear antigen (PCNA), heat shock protein 70 (HSP70) and caspase-3-positive cells in the distal intestine, were studied. Distal intestine somatic indices (DISI) were higher in inulin and lower in SBM compared to FM-fed fish. The low DISI caused by SBM corresponded with histological changes, neither of which was affected by OTC, despite a significant decrease in adherent bacteria count. Image analysis of PCNA-stained sections showed a significant increase in the proliferative compartment length in SBM-fed fish, accompanied by apparent increases in reactivity to HSP70 and caspase-3 along the mucosal folds, indicating induction of cellular repair and apoptosis, respectively. Fish fed the SBM diet had higher total number as well as a more diverse population composition of adherent bacteria in the distal intestine. Thus SBM-induced enteritis is accompanied by induction of distal intestinal epithelial cell protective responses and changes in microbiota. Putative involvement of bacteria in the inflammatory response merits further investigation.
\end{abstract}

Inflammation: Enteritis: Mucosal disorder: Diet: Intestine

The large surface area of the gastrointestinal tract is constantly bombarded by environmental antigens from the diet and microorganisms. The mucosal defence system must protect the body from pathogens and at the same time develop oral tolerance to antigens from the diet and commensal microbiota (see review by Chehade $\&$ Mayer, 2005). In man, gut mucosal disorders such as coeliac disease exemplifies loss of oral tolerance to a specific dietary antigen (gluten) whereas inflammatory bowel disease and Crohn's disease may represent loss of tolerance to the gut's microbiota. Histologically, severe cases include villous atrophy in coeliac disease and transmural ulceration in inflammatory bowel disease and Crohn's disease, as well as infiltrations of immune cells in the lamina propria in all three disorders (Fenoglio-Preiser et al. 1999). The aetiology and pathogenesis of these disorders are often complicated, involving genetic susceptibility, immune status, antigen dose and form, gut microbiota, and/or age of host at the time of exposure (Chehade \& Mayer, 2005).
An added dimension in the study of diet-gut interactions are the effects of prebiotics, non-digestible food ingredients, mostly from plants, that promote gut and host health by selectively stimulating the growth and/or activity of one or a limited number of beneficial bacterial species already resident in the intestine (Gibson \& Roberfroid, 1995; Grittenden \& Playne, 1996; Bauer et al. 2006). These may produce an environment unfavourable to the growth of pathogens. Inulin (IN), as an example, is a set of fructans, with monomers linked by $\beta$ (2-1) bonds (Roberfroid et al. 1998; Pool-Zobel et al. 2002), extracted from the chicory root (Cichorium intybus). The $\beta$ (2-1) linkage cannot be hydrolysed by pancreatic or brush border digestive enzymes in the proximal intestinal tract of man and domestic animals (Pool-Zobel et al. 2002). It is fermented in the large intestine or colon (Roberfroid, 2002; Flickinger et al. 2003) by beneficial bifidobacteria and other lactic acid-producing bacteria, enhancing their relative populations (Pool-Zobel et al.

Abbreviations: DISI, distal intestine somatic index; FM, fishmeal; IN, inulin; OTC, oxytetracycline; SBM, soyabean meal; PCL, proliferative compartment length; $\mathrm{PCL}_{\mathrm{BL}}$, PCL corrected for body length; PCNA, proliferating cell nuclear antigen; HSP, heat shock protein; TVC, total viable count.

* Corresponding author: Dr Anne Marie Bakke-McKellep, Norwegian School of Veterinary Science, fax +47 225973 10, email anne.mckellep@veths.no 
2002). Furthermore, its use as dietary fibre in man offers other potential health benefits, such as reduction in risk of colonic diseases, insulin-independent diabetes, obesity, osteoporosis and cancer (Grittenden \& Playne, 1996; Flickinger et al. 2003), blood cholesterol reduction, immune stimulation and enhanced vitamin synthesis (Jenkins et al. 1999).

In a teleost model of an intestinal mucosal disorder, full-fat and extracted soyabean meal (SBM), considered promising alternative protein sources to the traditionally used fishmeal (FM) in formulated salmonid diets, cause an inflammatory response in the distal intestine of Atlantic salmon (Salmo salar L.) and rainbow trout (Oncorhynchus mykiss Walbaum), putatively a hypersensitivity reaction pathohistologically similar to that of coeliac disease (van den Ingh \& Krogdahl, 1990; van den Ingh et al. 1991, 1996; Rumsey et al. 1994; Baeverfjord \& Krogdahl, 1996; Nordrum et al. 2000; Buttle et al. 2001; Krogdahl et al. 2003). The condition is accompanied by decreased growth as well as nutrient digestibility and absorption (Olli et al. 1994; Olli \& Krogdahl, 1995; Nordrum et al. 2000; Krogdahl et al. 2003) and a possible negative effect on disease resistance (Krogdahl et al. 2000). Bakke-McKellep et al. (2000) suggested that the differentiation of distal intestinal epithelial cells is affected and may be the cause of many of the pathophysiological responses observed. Olli \& Krogdahl (1995) and van den Ingh et al. (1996) concluded that alcohol-soluble components in the soyabean appear to be responsible for the negative effects of SBM, confirmed by the favourable results observed with soyabean concentrate (Olli et al. 1994; Krogdahl et al. 2000).

Recently, two investigations have evaluated the effect of SBM-based diets on gut microbiota of Atlantic cod, Gadus morhua L. (Ringø et al. 2006c), and rainbow trout in fresh water (Heikkinen et al. 2006). However, the possible involvement of microbiota in the pathogenesis of the SBM-induced enteritis in salmonids has not been investigated. On the other hand, some information is available on intestinal pathology of Arctic charr (Salvelinus alpinus L.) fed IN (Olsen et al. 2001). These pathological changes may be related to alterations in gut microbiota (Ring $\varnothing$ et al. 2006b). Based on the evidence from mammals, possible sequelae of altered microbiota composition can include loss of normal signalling necessary for intestinal barrier function, resulting in loss of immune tolerance to commensal bacteria, or loss of inhibition of pathogenic bacteria by non-pathogenic commensals (Hooper \& Gordon, 2001). In animal models of ulcerative colitis, animals raised in germfree environments do not develop disease (Hanauer, 2004). Direct evidence for these relationships in fish is lacking.

The goal of the current study was to supplement the information that already exists on the intestinal pathology of Atlantic salmon, comparing the effects brought about by dietary SBM with those putatively caused by IN in the diet and to evaluate the contribution of the intestinal microbiota to the inflammatory response to each of these components. Therefore, oxytetracycline (OTC), a broad-spectrum antibiotic, was included in the experimental diets to reduce and/or eliminate pathogenic as well as opportunistically pathogenic microbiota. When examining the effects of these dietary factors, three critical features of tissue response following injury were addressed: (1) mobilization of heat shock protein (HSP), reflecting cell repair as well as protective measures and inhibiting apoptosis up to a 'point of no return' (HSP70 proteins); (2) apoptosis (caspase-3); and (3) cell regeneration (proliferating cell nuclear antigen; PCNA), as manifested in the size of the proliferative compartment.

\section{Experimental methods adopted}

\section{Diets, animals and experimental design}

Six experimental diets (Table 1) were formulated to contain: (1) a reference diet based on FM; (2) a diet in which $250 \mathrm{~g}$ de-hulled, extracted and toasted $\mathrm{SBM} / \mathrm{kg}$ diet partially replaced FM and extruded wheat; or (3) a diet in which indigestible $75 \mathrm{~g}$ IN $/ \mathrm{kg}$ diet partially replaced extruded wheat. Each diet was formulated with and without $3 \mathrm{~g} \mathrm{OTC} / \mathrm{kg}$ diet. Diets were formulated to be iso-nitrogenous and iso-energetic on a crude protein and gross energy basis, and to contain 20$21 \%$ lipid and $54 \%$ crude protein (on a DM basis). They were supplemented with standard vitamin and mineral premixes. The SBM diets were supplemented with crystalline DL-methionine and fish oil to equal the content of methionine and $n$ 3 fatty acids, respectively, in the other diets. Diets were cold-pelleted with a pellet size of $3 \mathrm{~mm}$.

The experiment was conducted in accordance with laws and regulations that control experiments and procedures in live animals in Norway, as overseen by the Norwegian Animal Research Authority. At AKVAFORSK Research Station, Sunndalsøra, Norway, groups of thirty-seven Atlantic salmon (individual mean fish weight 172 (SEM 1) g) were randomly distributed to each of twelve fibreglass tanks supplied with seawater (surface area $1 \mathrm{~m}^{2}$; depth $50 \mathrm{~cm} ; 8-10^{\circ} \mathrm{C}$ ). The fish were allowed a $14 \mathrm{~d}$ adaptation period following distribution, during which they were fed the reference FM diet (Table 1). During the subsequent 3-week feeding trial, randomly selected, duplicate tanks of fish were fed one of six experimental diets. The final model gave a $3 \times 2 \times 2$ design, with diet and OTC as independent variables. Fish were continuously fed by automatic disc feeders. The growth rate was expected to be $1 \%$ of body weight/d, and the fish were fed $15 \%$ more than the expected need, assuming a feed conversion of 1.0 (Austreng et al. 1987). The feed intake appeared good when judged by visual observation. The water temperature during the experiment ranged from 8 to $10^{\circ} \mathrm{C}$, and the $\mathrm{O}_{2}$ saturation of the outlet water was above $80 \%$.

\section{Sampling}

All fish were euthanized in water with a lethal concentration of tricaine methanesulphonate (MS 222; Argent Chemical Laboratories, Redmond, WA, USA) and individually weighed and measured. Randomly selected fish from each tank were sampled for different analyses.

For calculation of organosomatic indices, the gastrointestinal tracts of five fish per tank were removed and divided into four sections: stomach, pyloric region, mid intestine (section between the distal-most caecum and the increase in diameter indicating the start of the distal intestine) and distal intestine (from the distal end of the mid intestine to the anus). Intestinal contents and adherent adipose and connective tissue were carefully removed. Samples were placed in tared tubes, frozen in liquid nitrogen and stored at $-80^{\circ} \mathrm{C}$ until weighing. 
Table 1. Diet formulations and chemical composition of the dietary treatments

\begin{tabular}{|c|c|c|c|c|c|c|}
\hline & \multicolumn{6}{|c|}{ Experimental diets } \\
\hline & FM & $\mathrm{FM}+\mathrm{OTC}$ & SBM & SBM + OTC & IN & $\mathrm{IN}+\mathrm{OTC}$ \\
\hline \multicolumn{7}{|l|}{ Ingredients (g/kg) } \\
\hline Fishmeal* $^{*}$ & 696 & 696 & 535 & 535 & 710 & 710 \\
\hline Soyabean meal $\dagger$ & - & - & 250 & 250 & - & - \\
\hline Inulin $\ddagger$ & - & - & - & - & 75 & 75 \\
\hline Oxytetracycline§ & - & 3 & - & 3 & - & 3 \\
\hline DL-Methionine\| & - & - & 2 & 2 & - & - \\
\hline Extruded wheat $\rrbracket$ & 164 & 161 & 61 & 58 & 76 & 73 \\
\hline Fish oil ${ }^{\star *}$ & 120 & 120 & 132 & 132 & 119 & 119 \\
\hline Vitamin/mineral premix†† & 20 & 20 & 20 & 20 & 20 & 20 \\
\hline \multicolumn{7}{|l|}{ Chemical composition } \\
\hline DM (\%) & 92.57 & 92.77 & $92 \cdot 30$ & $92 \cdot 26$ & $91 \cdot 83$ & 92.49 \\
\hline Lipid (\%) & $19 \cdot 40$ & $20 \cdot 20$ & $19 \cdot 20$ & $19 \cdot 10$ & $17 \cdot 80$ & $18 \cdot 20$ \\
\hline Crude protein (\%) & $50 \cdot 18$ & $50 \cdot 08$ & $50 \cdot 29$ & $50 \cdot 06$ & $50 \cdot 11$ & $49 \cdot 41$ \\
\hline Starch (\%) & 8.32 & $7 \cdot 89$ & 2.96 & $2 \cdot 70$ & 3.32 & 3.63 \\
\hline Ash (\%) & 11.63 & $11 \cdot 19$ & $10 \cdot 41$ & $10 \cdot 30$ & 11.67 & $11 \cdot 72$ \\
\hline 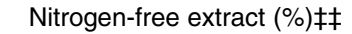 & 3.04 & 3.41 & 9.44 & $10 \cdot 1$ & 8.93 & 9.53 \\
\hline Gross energy $(\mathrm{MJ} / \mathrm{kg})$ & 20.92 & $21 \cdot 27$ & $21 \cdot 23$ & $21 \cdot 32$ & $20 \cdot 61$ & $20 \cdot 87$ \\
\hline
\end{tabular}

FM, fish meal; IN, inulin; OTC, oxytetracycline; SBM, soyabean meal.

* Norse LT-94 (Vedde Sildoljefabrikk, Langevåg, Norway).

† Dehulled, extracted and toasted soyabean meal (Hamlet, Horsens, Denmark).

†Frutanimal ND (Suiker Unie, Dinteloord, The Netherlands).

$\S$ Oxytetracycline hydrochloride (Norsk medisinaldepot, Oslo, Norway).

|| Degussa (Hanau, Germany).

In Nutreco ARC (Stavanger, Norway).

${ }^{* \star}$ Nutreco ARC (Stavanger, Norway).

††FeedTech (Ås, Norway).

扭 As calculated from 100 - ([100 - \% DM] + \% lipid + \% crude protein + \% starch + \% ash).

For histological evaluation and immunohistochemical analyses of markers for cellular proliferation (PCNA), programmed cell death or apoptosis (caspase-3) and stressrelated protein degenerative and/or regenerative processes (HSP70), three fish per tank were sampled. Gastrointestinal tracts were removed, prepared as described earlier, and samples of mid and distal intestines $(5 \times 5 \mathrm{~mm}$ each $)$ fixed in neutral buffered formalin $(4 \%, \mathrm{pH} 7 \cdot 2)$ for $24 \mathrm{~h}$ and subsequently stored in $70 \%$ ethanol. Additional samples of distal intestine were frozen in liquid propane chilled with liquid nitrogen and stored at $-80^{\circ} \mathrm{C}$ until immunohistochemical analyses could be performed.

Adherent and non-adherent bacteria from the mid and distal intestine were isolated from three additional fish per tank as previously described (Ring $\varnothing, 1993$ ). Briefly, the gastrointestinal tract was dissected as described earlier and the contents (digesta) from the mid and distal intestine were transferred to sterile plastic bags. The corresponding intestines were thoroughly rinsed three times in $2 \mathrm{ml}$ sterile $0.9 \%$ saline to remove non-adherent bacteria and likewise transferred to separate sterile plastic bags.

\section{Histological screening of intestinal tissue}

Samples for histological analysis were processed according to standard histological methods (Histological Laboratory, Norwegian School of Veterinary Science). Sections approximately $5 \mu \mathrm{m}$ thick were cut parallel to the longitudinal direction of the intestine, in the distal intestine perpendicular to the macroscopically visible circular folds (complex folds), and stained with haematoxylin and eosin. Intestinal samples were scored based on morphological changes described by Baeverfjord
\& Krogdahl (1996). Mid intestine scores were based on evaluation of widening and cellular infiltration of the lamina propria, and degree of enterocyte vacuolization. Lamina propria scores (0-3) were assigned as: 0, normal; 1, mild; 2 moderate; 3, marked widening and infiltration. Enterocyte vacuolization scores (0-1) were: 0 , slight vacuolization; 1 , no vacuolization. Half $(0 \cdot 5)$ points were included. Total mid intestine scores were classified as: $0-1$, normal; $>1-3$, moderate pathological changes; $>3-4$, severe change. Distal intestine scores were based on evaluation of the lamina propria, enterocyte vacuolization and mucosal fold height. Lamina propria scores were assigned similarly as mid intestine scores. Enterocyte vacuolization scores ( $0-3)$ were: 0 , highly vacuolated; 1 , mildly reduced; 2 , moderately reduced; 3 , markedly reduced (absence). Mucosal fold height scores were: 0 , normal (long); 1 , medium; 2 , short. Half $(0.5)$ points were included. Total scores of distal intestine were classified as: $0-1$, normal; $>1-5$, moderate pathological change; $>5-8$, severe change.

\section{Immunohistochemistry}

The immunohistochemical protocol given later represents the result following a series of laboratory tests, including comparison between cryostat and formalin-fixed paraffin sections and various de-masking procedures of paraffin sections. Thus, we arrived at three different procedures corresponding to the particular antigen that was to be detected: PCNA, caspase- 3 and HSP70. With respect to caspase-3 and HSP70, formalin-fixed paraffin sections were used. For PCNA, cryostat sections were used. The cryostat sections of $7 \mu \mathrm{m}$ in thickness were cut as described earlier, placed on glass slides, thawed and air-dried for $1 \mathrm{~h}$ before fixation in $4 \%$ buffered formalin for $2 \mathrm{~min}$ and 
$70 \%$ alcohol for $10 \mathrm{~min}$. With respect to the paraffin-embedded sections for caspase-3 and HSP70, sections were subjected to deparaffinization using xylene at $58^{\circ} \mathrm{C}$ and subsequent rehydration. For HSP70, de-masking of the sections was done by hydrated autoclaving at $121^{\circ} \mathrm{C}$ for $15 \mathrm{~min}$ in $0.01 \mathrm{M}$-citrate buffer $\mathrm{pH}$ 6.0. For caspase, de-masking of sections was done by treatment with $1 \mathrm{mg} / \mathrm{ml}$ trypsin (No. 215230; Difco, BD Biosciences, Sparks, MD, USA) in a $0 \cdot 1 \mathrm{M}$-Tris-HCl buffer, $\mathrm{pH} 8.0$ at $37^{\circ} \mathrm{C}$ for $40 \mathrm{~min}$. To inhibit endogenous peroxidase, the sections were treated with phenyl hydrazine (Fluka, Buchs, Switzerland), $0.05 \%$ PBS for $40 \mathrm{~min}$ at $37^{\circ} \mathrm{C}$. To avoid nonspecific binding, sections were incubated for $20 \mathrm{~min}$ with $5 \%$ bovine serum albumin in Tris-buffered saline containing normal goat serum diluted 1:50.

Primary antibodies included a rabbit polyclonal antibody against caspase-3 (Anti-ACTIVE ${ }^{\circledR}$ Caspase-3 pAb, No. G7481; Promega, Southampton, UK), a mouse monoclonal anti-HSP70 (clone BRM-22, No. H5147; Sigma-Aldrich, Oslo, Norway) and a mouse monoclonal anti-PCNA ( $\alpha$-PCNA, clone PC10, No. M0879; Dako, Glostrup, Denmark). An indirect immunoperoxidase method (EnVision ${ }^{\circledR}$ System, Peroxidase; Dako) was used for immunohistochemistry. The labelling was performed according to the manufacturer's instructions with some modifications. The blocking solution was removed and the sections were incubated with the primary monoclonal antibodies for $30 \mathrm{~min}$. Between each step in the procedure, apart from the blocking step, the sections were washed three times with PBS for $5 \mathrm{~min}$. The incubation time for the secondary antibody, peroxidase-labelled polymer conjugated with goat anti-mouse or, as appropriate, anti-rabbit Ig, was $30 \mathrm{~min}$. All incubations took place in a humid chamber at room temperature. The peroxidase activity was detected with a 3-amino-9-ethylcarbazole kit from Dako (No. K4008), for $20 \mathrm{~min}$. The sections were counterstained either with haematoxylin for $1 \mathrm{~min}$ or with methyl green (No. S1962; Dako) and mounted with polyvinyl alcohol under a coverslip before examination. Control sections were incubated with $1 \%$ bovine serum albumin in Tris-buffered saline instead of the primary antibody.

\section{Data-assisted image analysis}

Cryostat sections stained for PCNA and counterstained with methyl green, as described earlier, were examined by light microscopy (Leica DM RXA microscope; Leica Microsystems AG, Wetzlar, Germany). Digital images of each section were taken with a Spot RT Slider digital camera (Diagnostic Instruments Inc., Sterling Heights, MI, USA), utilizing the Spot Image Capture Software, version 3.0.4 (Diagnostic Instruments Inc.). Digital images taken at $200 \times$ magnification were used for morphometric measurement using morphometric software ImagePro Plus, version 4.5 (Media Cybernetics, Silver Spring, MD, USA). Groups of adjacent epithelial cells located in the basal (proliferative compartment) areas of the simple mucosal folds (as opposed to the complex folds) that stained positively for PCNA were measured $(\mu \mathrm{m})$. Proliferative compartments that appeared closed off to the lumen or circular were excluded since this was an indication that the tissue or parts of the tissue had been sectioned obliquely.

From each section, sixteen to thirty-seven proliferative compartments were measured (means 26, 23 and 28 from
FM, IN and SBM, respectively). The mean PCNA-positive proliferative compartment length (PCL) was calculated using all measurements of PCNA-positive compartments in each section. In order to reduce variation due to differences in fish size, PCL was corrected for body weight and body length.

\section{Bacteriology}

Mid and distal intestinal segments and their respective digesta were homogenized in a Stomacher (Seward Laboratory, London, UK). Homogenates of the intestinal segments and the digesta were diluted in sterile $0.9 \%$ saline and appropriate dilutions spread on the surface of tryptic soya agar (Difco) plates (with $5 \%$ glucose and $1 \% \mathrm{NaCl}$ added). The plates were incubated at $12^{\circ} \mathrm{C}$ and inspected regularly for up to 4 weeks. After enumeration (Ring $\varnothing, 1993$ ), a representative selection of colonies, 1320 autochthonous (adherent) and allochthonous isolates were subcultured until purity was achieved. Whenever necessary, the isolates were tested for up to fifty-two biochemical and physiological properties as shown by Ring $\varnothing$ \& Olsen (1999). One hundred strains isolated from each rearing group were further characterized by sequencing the 16S rRNA gene.

DNA was extracted from selected isolates by the method described by Pitcher et al. (1989). The pellet was resuspended in $100 \mu \mathrm{l}$ deionized water, and the concentration of DNA was determined spectrophotometrically at wavelength $260 \mathrm{~nm}$. The DNA was stored at $-20^{\circ} \mathrm{C}$ until analysis.

PCR amplifications of the 16S rRNA genes were performed using the forward primer 27F (AGAGTTTGATCMTGGCTCAG) and the reverse primer 1491R (GGTTACCTTGTTACGAC TT). A detailed description is given by Ring $\varnothing$ et al. $(2006 b)$. The amplicons were digested with the 4 bp restriction enzyme HaeIII (New England Biolabs, Ipswich, MA, USA). Direct sequencing of PCR products was performed with $27 \mathrm{~F}$ as the sequencing primer. The cycle-sequencing reaction was performed in a GeneAmp PCR System 2400, and labelled fragments were separated on a 310 Automated Genetic Analyzer (Applied Biosystems, Oslo, Norway), both procedures according to the manufacturer's protocols (Applied Biosystems). The partial sequences of the $16 \mathrm{~S}$ rRNA gene were analysed and edited using BioEdit. An initial BLAST-search in GenBank retrieved the taxonomic groups for which they showed the highest identities. For each sequence, an alignment was constructed with all members of the group. Phylogenetic inference by the neighbour-joining method was performed using the PHYLIP package bootstrap. The species with the closest phylogenetic relationship with the isolate was identified and selected for more comprehensive analyses. The twenty-nine sequences corresponding to the bacterial isolates and twenty-one sequences from GenBank were aligned with ClustalW in the BioEdit package.

\section{Calculations}

Organosomatic indices were calculated as follows:

$$
\begin{aligned}
& \text { Organosomatic index }(\%) \\
& =[\text { tissue weight }(\mathrm{g}) / \text { body weight }(\mathrm{g})] \times 100 \text {. }
\end{aligned}
$$


Distal intestine somatic index relative to body length

$\left(\right.$ DISI $\left._{\mathrm{BL}} ; \mathrm{g} / 100 \mathrm{~cm}\right)=[$ distal intestine weight $(\mathrm{g}) /$

fork length $(\mathrm{cm})] \times 100$.

PCNA values were calculated as follows:

PCNA - positive PCL corrected for body length

$\left(\mathrm{PCL}_{\mathrm{BL}} ; \mu \mathrm{m} / \mathrm{m}\right)=[\mathrm{PCL}(\mu \mathrm{m}) /$ body length $(\mathrm{cm})] \times 100$.

\section{Statistical analysis}

Statistical analyses were conducted using SAS statistical software, version 8.02 (SAS Institute Inc., Cary, NC, USA). Two-way ANOVA (general linear model) was performed with diet and OTC supplementation as class variables. Intestinal region was included as a third class variable (three-way ANOVA) for analysis of total bacterial population levels. When interactions were not significant marginal means were compared using Duncan's multiple range tests. When interactions were significant, post-hoc pair-wise comparisons (LSMEANS/PDIFF procedure) were used to compare differences within each combination of class variables. The level of significance was established at $\alpha=0.05$ for all tests. All analyses were performed on tank means (means of all sampled fish per tank) except microbial analysis, which was performed on means of six fish per treatment. Data for microbial analysis were log transformed prior to statistical analysis.

\section{Results}

No mortalities occurred during the feeding trial. Growth effects were not a goal of the present study, and the duration of the feeding period was too short for accurate evaluation of an effect on growth. Diet effects are presented first, with OTC inclusion and interactions between diet and OTC following for the various parameters.

\section{Body parameters}

Diet did not significantly affect body weight or body length. Irrespective of OTC inclusion, final mean weights were 243 (SEM 7), 238 (SEM 2) and 237 (SEM 2) g, and final mean lengths (fork length) were 26.7 (SEM 0.2), 26.5 (SEM 0.8) and 26.5 (SEM 0.0) $\mathrm{cm}$ for FM, SBM and IN diets, respectively (four tanks per diet).

OTC inclusion did not affect body weight or body length significantly. Irrespective of diet, final mean weights were 241 (SEM 4) and 237 (SEM 2) g, and final mean lengths were $26.6(\operatorname{SEM} 0 \cdot 1)$ and $26.5($ SEM $0 \cdot 1) \mathrm{cm}$ for diets without and with OTC, respectively (six tanks per OTC inclusion level). No interaction between diet and OTC inclusion was observed.

\section{Organosomatic indices}

Diet did not affect stomach, pyloric caeca or mid intestinal somatic indices significantly (Table 2). During sampling the distal intestine of the SBM-fed fish appeared macroscopically more translucent, indicating a thinner intestinal wall. Fish fed SBM diets had a lower DISI compared to FM-fed fish, while IN-fed fish had a higher DISI (Table 2). The estimation of the DISI corrected to equal body length showed the same statistical pattern as the DISI corrected to body weight. OTC supplementation did not affect any of the organosomatic indices significantly. Interaction between OTC and diet was not observed either.

\section{Histological screening of intestinal tissue}

Few fish (one, two and two fish fed FM, SBM and IN diets, respectively) showed changes in the enterocyte columnar epithelium and lamina propria of mid intestinal sections. Statistical analysis did not reveal significant effects of the diet on histological scores (Table 3). However, the mid intestine of six of twelve SBM-fed fish and six of twelve IN-fed fish showed moderate leucocytic cell infiltration of the muscular layers.

Table 2. Mean organosomatic indices of sections of the gastrointestinal tract of Atlantic salmon fed the different experimental diets (two tanks per diet group; five fish per tank)*

\begin{tabular}{|c|c|c|c|c|c|}
\hline Diet & STSI (\% BW) & PISI (\% BW) & MISI (\% BW) & $\mathrm{DISI}_{\mathrm{BW}}(\% \mathrm{BW})$ & $\operatorname{DISI}_{\mathrm{BL}}(\mathrm{g} / \mathrm{m})$ \\
\hline FM & 0.57 & 1.66 & $0 \cdot 19$ & $0.44^{\mathrm{b}}$ & $4.00^{\mathrm{b}}$ \\
\hline $\mathrm{FM}+\mathrm{OTC}$ & 0.56 & 1.48 & $0 \cdot 17$ & $0.41^{\mathrm{bc}}$ & $3.82^{\mathrm{b}}$ \\
\hline SBM & 0.56 & 1.76 & 0.19 & $0.33^{\mathrm{d}}$ & $3.02^{\mathrm{c}}$ \\
\hline SBM + OTC & 0.59 & $1 \cdot 76$ & $0 \cdot 19$ & $0.36^{\mathrm{cd}}$ & $3 \cdot 10^{\mathrm{C}}$ \\
\hline IN & 0.57 & 1.94 & 0.20 & $0.52^{\mathrm{a}}$ & $5 \cdot 26^{\mathrm{a}}$ \\
\hline $\mathrm{IN}+\mathrm{OTC}$ & 0.61 & 1.83 & 0.20 & $0.52^{\mathrm{a}}$ & $4.97^{\mathrm{a}}$ \\
\hline Pooled SE & 0.010 & 0.068 & 0.005 & 0.010 & $0 \cdot 131$ \\
\hline \multicolumn{6}{|l|}{ Statistics ( $P$ values) } \\
\hline Significance of model & $0 \cdot 1844$ & 0.1329 & 0.1318 & 0.0003 & 0.0006 \\
\hline Significance of diet & 0.2349 & 0.0441 & 0.0612 & $<0.0001$ & $<0.0001$ \\
\hline Significance of OTC & $0 \cdot 1319$ & 0.2720 & 0.3728 & 0.9933 & 0.4277 \\
\hline Significance of diet $\times$ OTC & 0.2056 & 0.6720 & 0.2771 & 0.1364 & 0.6023 \\
\hline
\end{tabular}

$\mathrm{BW}$, body weight; $\mathrm{DISI}_{\mathrm{BL}}$, distal intestine somatic index relative to body length; $\mathrm{DISI}_{\mathrm{BW}}$, distal intestine somatic index relative to body weight; FM, fish meal; IN, inulin; MISI, mid intestine somatic index; OTC, oxytetracycline; PISI, pyloric intestine (caeca) somatic index; SBM, soyabean meal; STSI, stomach somatic index.

${ }_{a, b, c, d}$ Mean values within a column with unlike superscript letters were significantly different $(P<0.05)$

${ }^{\star}$ For details of procedures, see p. 699 
Table 3. Statistical analysis of mean histology scores for mid and distal intestine and immunohistochemical measurements of proliferating cell nuclear antigen (PCNA)-positive proliferative compartments in the distal intestine of fish fed the different experimental diets (two tanks per diet group; three fish per tank)*

\begin{tabular}{lccccc}
\hline \multirow{2}{*}{ Diet } & \multicolumn{2}{c}{ Histology scores } & & \multicolumn{2}{c}{ PCNA measurements } \\
\cline { 2 - 3 } \cline { 5 - 6 } & Mid intestine† & Distal intestine $\neq$ & & PCL $(\mu \mathrm{m})$ & PCL $_{\mathrm{BL}}(\mu \mathrm{m} / \mathrm{m})$ \\
\hline FM & 0.33 & $0.00^{\mathrm{b}}$ & & $239^{\mathrm{bc}}$ & $780^{\mathrm{bc}}$ \\
FM + OTC & 0.92 & $0.08^{\mathrm{b}}$ & & $217^{\mathrm{c}}$ & $716^{\mathrm{bc}}$ \\
SBM & 0.67 & $5.17^{\mathrm{a}}$ & & $386^{\mathrm{a}}$ & $1262^{\mathrm{a}}$ \\
SBM + OTC & 1.33 & $0.83^{\mathrm{a}}$ & & $380^{\mathrm{a}}$ & $1192^{\mathrm{a}}$ \\
IN & 1.50 & $0.33^{\mathrm{b}}$ & & $281^{\mathrm{b}}$ & $884^{\mathrm{b}}$ \\
IN + OTC & 0.50 & $0.50^{\mathrm{b}}$ & & $211^{\mathrm{c}}$ & $666^{\mathrm{c}}$ \\
Pooled SE & 0.17 & & & 14.9 & 50.8 \\
Statistic $(P$ values) & 0.0695 & $<0.0001$ & & 0.0004 & 0.0006 \\
Significance of model & 0.2775 & $<0.0001$ & & $<0.0001$ & $<0.0001$ \\
Significance of diet & 0.6851 & 0.9222 & & 0.0361 & 0.0297 \\
Significance of OTC & 0.0222 & 0.7228 & & 0.1722 & 0.3027 \\
Significance of diet $\times$ OTC & & & & & \\
\hline
\end{tabular}

$P C L$, proliferative compartment length; $P C L_{B L}$, proliferative compartment length corrected for body length; $F M$, fish meal; IN, inulin; OTC, oxytetracycline; SBM, soyabean meal.

a,b,c Mean values within a column with unlike superscript letters were significantly different $(P<0.05)$

${ }^{\star}$ For details of procedures, see pp. 699-700.

† Maximum score $=4$.

$\ddagger$ Maximum score $=8$.

Of the five fish that showed changes in the enterocyte columnar epithelium and/or lamina propria of the mid intestine, two were fed OTC-free diets and three were fed OTC-supplemented diets. OTC inclusion did not affect histological scores; however, the overall model $P$ value was nearly significant $(P=0.0695)$ due to the interaction term (diet $\times$ OTC supplementation). The leucocyte infiltration of the muscular layers occurred in eight of eighteen fish fed OTC-free diets and four of eighteen fish fed OTC-supplemented diets.

All fish fed the FM diets and eleven of twelve fish fed the IN diets showed normal morphology of the distal intestine, characterized by the presence of well-differentiated enterocytes with many absorptive vacuoles, though there appeared to be increased vacuolization in fish fed IN diets. In contrast, moderate and marked morphological changes were observed in all fish fed the SBM diet. Morphological changes included variable degrees of mixed leucocyte cell infiltration, including eosinophilic granular cells, of the lamina propria and reduced vacuolization of the enterocytes, and shortening of mucosal folds (Fig. 1). Feeding SBM resulted in a significantly higher histological score than feeding FM or IN (Table 3). No significant difference was observed between the FM and IN diets. Neither OTC supplementation nor interaction affected histology scores.

\section{Immunohistochemistry of the distal intestine}

As antibodies against PCNA, HSP70 and caspase- 3 in salmon are unavailable, the antibodies developed against mammalian antigens were evaluated initially based on their assumed pattern of reactivity within tissue sections of controls. Thus, the antibody against PCNA reacted against a population of dividing epithelial cells at the base of the mucosal folds as expected (Fig. 2). Likewise, antibodies against caspase-3 reacted against epithelial cells close to the tips of the complex and simple folds (Figs 3 and 4). Sometimes reactivity was seen in cells extruded from the epithelium, corresponding to the expected extrusion following senescent apoptosis. As the applied antibodies against HSP70 are claimed to detect constitutive as well as inducible members of the HSP family in a wide spectrum of mammalians (compare product description earlier), a predictable pattern of reactivity of this antibody was less obvious. As it turned out, the reactivity was confined to the upper 10-20\% of the folds, and in some folds apparently was absent (Fig. 3). A population of epithelial cells at the tips of the complex folds appeared to react more consistently. At the cellular level, reactivity was seen in the nucleus as well as in the cytoplasm, although not always in both sites.

When the different diets were compared, OTC inclusion had no apparent effect on the findings mentioned earlier. Therefore only groups fed the diets not containing OTC were analysed more thoroughly for HSP70 and caspase- 3 reactivity. A change of reaction pattern was observed as a response to SBM, in which the SBM diets caused an increase in the PCNA-positive proliferative compartment at the base of the folds (Fig. 2), accompanying a marked enhancement of HSP70 and caspase- 3 reactivity in epithelial cells at the tips of the simple folds (Figs 3 and 4). In contrast, and as emphasized earlier, epithelial cells at the tips of the complex folds sometimes showed reaction even in the controls, albeit less extensively than in SBM-fed fish.

Digital image analysis confirmed that SBM caused a significant increase in PCL at the base of the folds compared to fish fed FM and IN diets (Table 3). No difference was found between FM and IN diets. PCL $\mathrm{BL}_{\mathrm{BL}}$ was also affected by diet. Fish fed the SBM diet had a significantly higher PCL $_{\mathrm{BL}}$ than fish fed FM and IN diets, but the FM and IN treatments were not significantly different. Fish fed diets containing OTC had lower PCL $\mathrm{BL}_{\mathrm{BL}}$ than fish fed diets without OTC, but no interaction between diet and OTC inclusion was observed. 

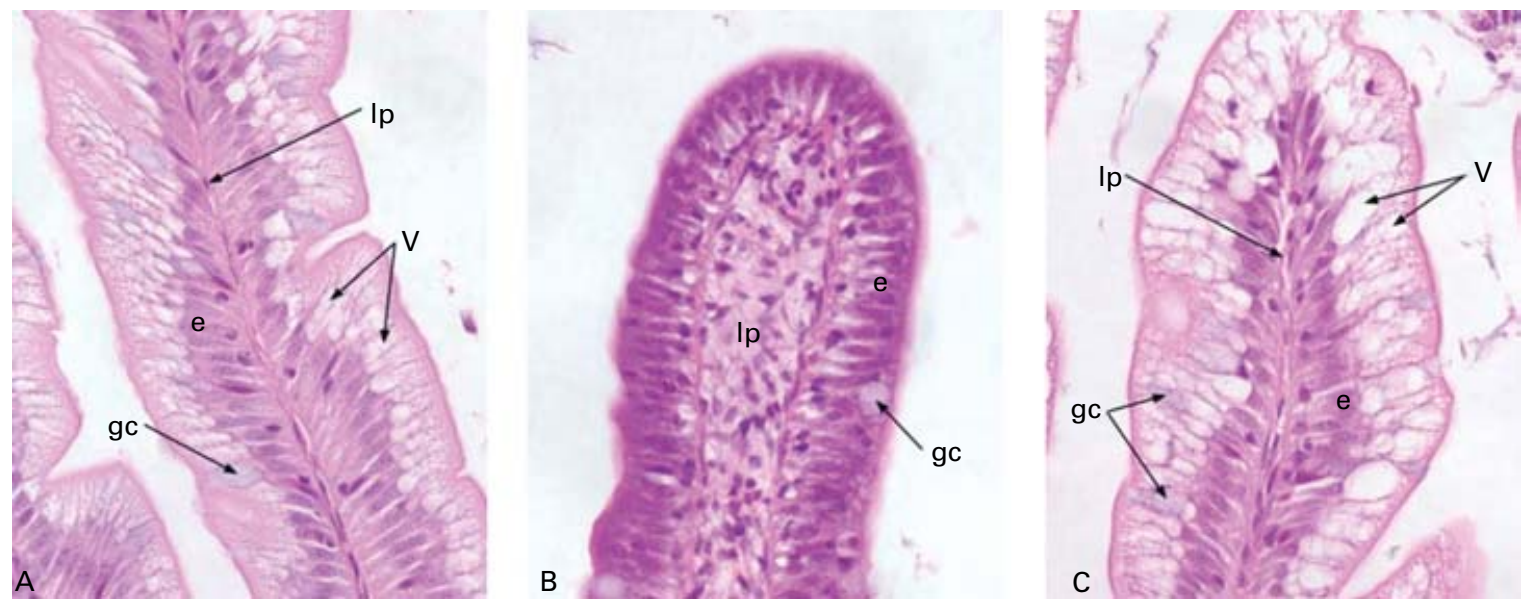

Fig. 1. Distal intestinal histology (haematoxylin and eosin) of fish fed (A) fishmeal (FM), (B) soyabean meal (SBM) and (C) inulin $(\mathrm{IN})$ diets $(\times 400)$. e, epithelial layer; gc, goblet cell; Ip, lamina propria; v, absorptive vacuoles.

\section{Bacteriology}

Diet, OTC and intestinal region affected intestinal bacterial population levels (Table 4) and all interactions were statistically significant. In order to present results in a concise and meaningful manner only those that are biologically relevant are presented. Results are presented as the log of total viable count (TVC) of bacteria isolated from $1 \mathrm{~g}$ (wet weight) of tissue or digesta. The influences of diet and intestinal region and the interaction between them are presented for data of non-OTC-supplemented diets due to the confounding effect of OTC in the three-way interaction.

In fish fed diets without OTC, there was an overall trend of higher total bacterial levels in digesta (mean log 4.67 and 4.75 for mid and distal intestine, respectively) compared to adherent population levels (mean $\log 3.73$ and 4.09, respectively). Population levels in mid and distal intestinal digesta did not differ significantly, but adherent population levels did (distal intestine $>$ mid intestine). However, within specific diets, IN-fed fish had similar adherent and digesta levels in the mid as well as distal intestine, and FM-fed fish had higher levels in digesta of the mid compared to distal intestine. In SBM-fed fish, higher digesta compared to adherent population levels were found in both intestinal regions. Overall, fish fed SBM diets had the highest bacterial population level (mean $\log 4.76)$, followed by FM (4.40) and IN (3.78). The orders of total bacterial population levels ranked by diet in each of the intestinal regions are shown in Table 4.

OTC inclusion significantly reduced total bacterial population levels across diets and intestinal regions from an overall mean $\log$ TVC of 4.31 to $2 \cdot 36$. OTC inclusion caused a greater reduction in bacteria from digesta than mucosa (approximately 500- and 10-fold log reductions, respectively). The greatest effect occurred in the distal intestine digesta (log TVC 1.55; reduction by $\log 3.20$ ), followed by mid intestine digesta (2.39; reduction by $2 \cdot 28)$. Adherent bacterial populations were also reduced but to a lesser extent: mid intestine, $2 \cdot 05$ (reduced by 1.68); distal intestine, 3.47 (reduced by 0.62). An exception was the large reduction in adherent bacteria in the mid intestine of the FM-fed group $(0 \cdot 24$; reduced by $3 \cdot 39)$. When OTC was included in the diet, the mean log TVC of SBM- and FM-fed fish did not differ significantly $(2 \cdot 65$ and $2 \cdot 77$, respectively)
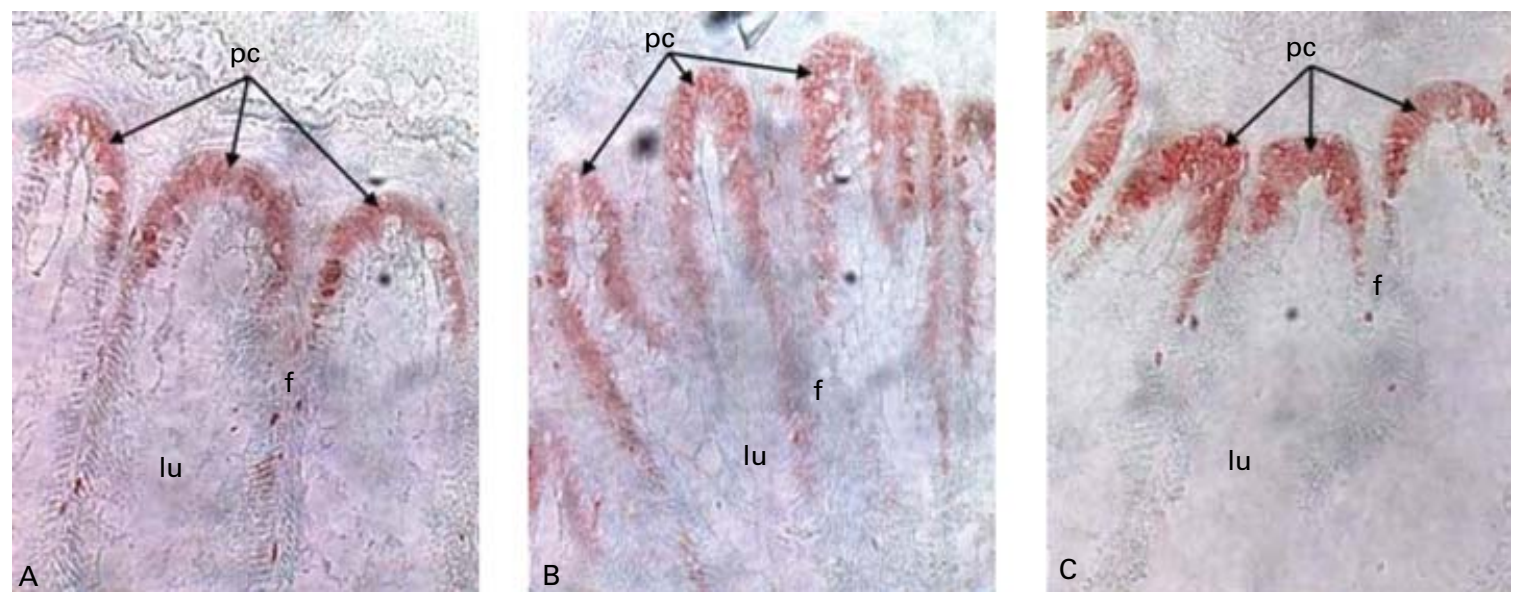

Fig. 2. Cryosections of salmon distal intestine, immunohistochemical detection of proliferating cell nuclear antigen (PCNA) in fish fed (A) fishmeal (FM), (B) soyabean meal (SBM) and (C) inulin (IN) diets. Antibody against PCNA reacted against a population of dividing epithelial cells at the base of the simple intestinal folds. SBM (B) caused a significant increase in the length of the proliferative cell compartment compared to fish fed FM (A) and IN (C) diets. f, mucosal folds; lu, lumen; pc, proliferative compartment. 

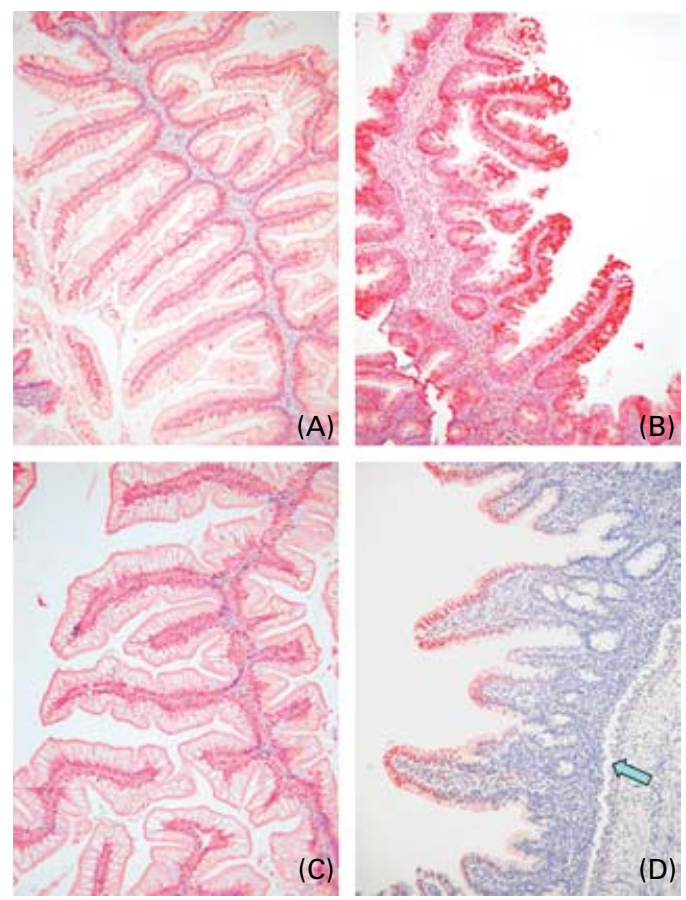

Fig. 3. Formalin-fixed sections of salmon distal intestine, immunohistochemical detection of heat shock protein 70 (HSP70) and caspase-3. (A) Fish meal diet (FM), HSP70. Very scarce reactivity is seen in the absorptive epithelial cells (compare with (B)). (B) Soyabean meal diet (SBM), HSP70. The majority of the epithelial cells at the tips of the simple mucosal folds are reactive. (C) Fish meal diet (FM), anti-active caspase-3. Scarce reactivity is seen in the absorptive epithelial cells. (D) SBM, anti-active caspase-3. The epithelial cells at the tips of the folds are reactive. The folds are shortened and atrophied, often lacking a subdivision in simple and complex folds. Note the leucocyte infiltration of the lamina propria and submucosa. $\Leftarrow$, Stratum compactum. All sections counterstained with haematoxylin.

but were greater than in IN-fed fish (1.66). OTC had a greater effect on the reduction of total bacterial population levels in SBM- and IN-fed fish (reduction by 2.12 each) than in FM-fed fish (reduction by 1.63).

In total, 1320 adherent and allochthonous bacterial colonies were isolated from the digestive tract of Atlantic salmon. Traditional culture-based microbiology showed that the microbiota

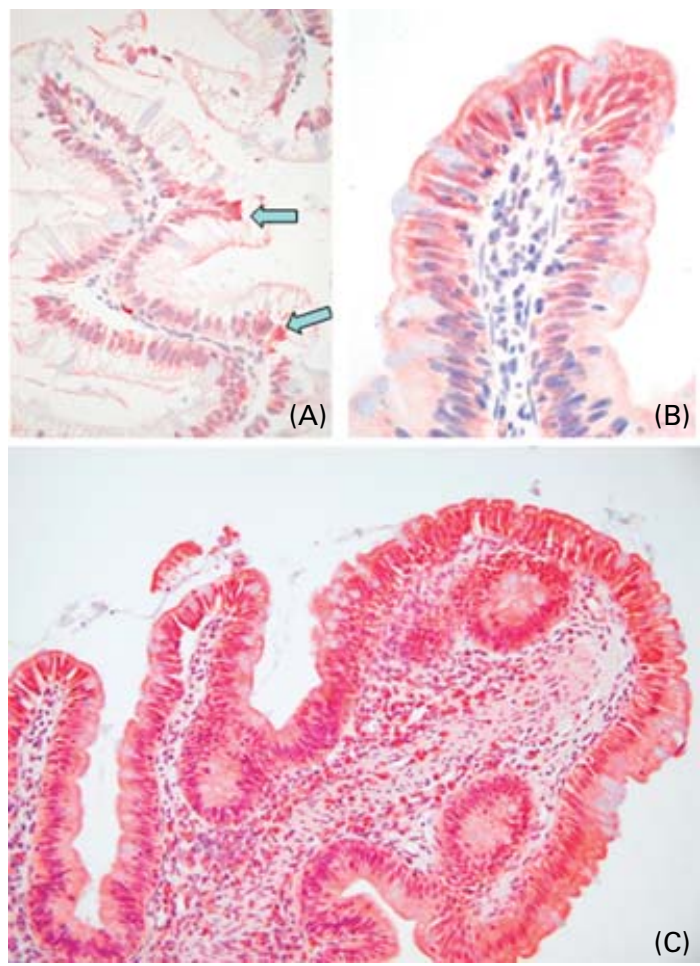

Fig. 4. Formalin-fixed sections of salmon distal intestine, immunohistochemical detection of anti-active caspase-3. (A) Fish meal diet (FM) (control). In control salmon caspase reactivity (red) typically affects individual cells and probably represents senescent cells close to the tips of the simple folds. Note the reactive epithelial cells $(\hookleftarrow)$. The staining is seen primarily in the nuclei. Due to the vacuolization that is typical for the absorptive epithelial cells in this segment of the intestine, the staining of cytoplasm is not always evident. (B) Soyabean meal diet (SBM). Most of the epithelial cells at the tip of this simple fold are reactive. Both cytoplasmic and nuclear staining is seen. (C) SBM. Most of the epithelial cells at the tip of this complex fold are reactive. Note the stretches with reactive (red) epithelial cells and the large number of leucocytes in the lamina propria, many of which are reactive. All sections counterstained with haematoxylin.

species profiles were different between the treatment groups, as clearly demonstrated in Fig. 5. Of the identified isolates, twenty-four genera and species were identified from fish fed FM (Table 5A) and twenty-six genera and species from fish fed

Table 4. Means of log total viable counts/g mucosa (adherent) or digesta for bacteria isolated from the mid and distal intestinal tract of fish fed the different experimental diets

(two tanks per diet group; three fish per tank)*

\begin{tabular}{|c|c|c|c|c|}
\hline Diet & Mid intestine adherent & Mid intestine digesta & Distal intestine adherent & Distal intestine digesta \\
\hline FM & $3.63^{b}$ & $5 \cdot 21^{a}$ & $3.92^{b}$ & $4.83^{b}$ \\
\hline $\mathrm{FM}+\mathrm{OTC}$ & $0 \cdot 24^{d}$ & $3 \cdot 38^{b}$ & $3 \cdot 80^{\mathrm{b}}$ & $3.68^{c}$ \\
\hline SBM & $3.99^{a}$ & $5 \cdot 21^{a}$ & $4 \cdot 41^{a}$ & $5 \cdot 42^{\mathrm{a}}$ \\
\hline SBM + OTC & $2.99^{c}$ & $3.43^{b}$ & $3.59^{c}$ & $0.59^{d}$ \\
\hline IN & $3.56^{b}$ & $3 \cdot 61^{b}$ & $3.95^{\mathrm{b}}$ & $3.99^{c}$ \\
\hline $\mathrm{IN}+\mathrm{OTC}$ & $2 \cdot 90^{\mathrm{C}}$ & $0.35^{c}$ & $3.02^{d}$ & $0.38^{d}$ \\
\hline Pooled SE & $0 \cdot 12$ & $0 \cdot 12$ & 0.05 & $0 \cdot 15$ \\
\hline \multicolumn{5}{|l|}{ Statistic ( $P$ values) } \\
\hline Significance of model & $<0.0001$ & $<0.0001$ & $<0.0001$ & $<0.0001$ \\
\hline Significance of diet & $<0.0001$ & $<0.0001$ & $<0.0001$ & $<0.0001$ \\
\hline Significance of OTC & $<0.0001$ & $<0.0001$ & $<0.0001$ & $<0.0001$ \\
\hline Significance of diet $\times$ OTC & $<0.0001$ & $<0.0001$ & $<0.0001$ & $<0.0001$ \\
\hline
\end{tabular}

M, fish meal; IN, inulin; OTC, oxytetracycline; SBM, soyabean meal.

$a, b, c, d$ Mean values within a column with unlike superscript letters were significantly different $(P<0.05)$.

${ }^{*}$ For details of procedures, see p. 702. 


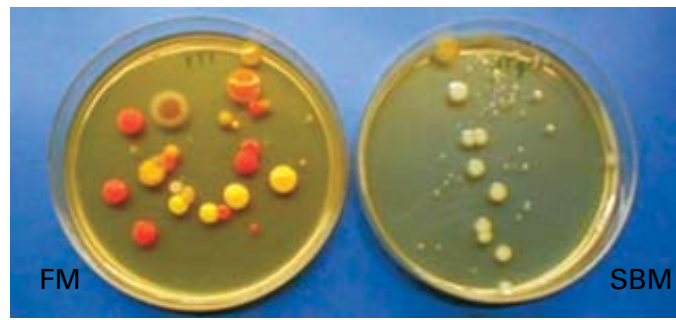

Fig. 5. Tryptic soya agar plates showing adherent bacteria isolated from the distal intestine of Atlantic salmon (Salmo salar L.) fed fish meal (FM) and soyabean meal (SBM) diets.

SBM (Table 5B), but only sixteen genera and species from fish fed IN (Table 5C). The bacteria Nocardia corynebacteroides and Rathayibacter tritici were exclusively found in the FM-fed fish; Vibrio spp., Arthrobacter agillis, Brachybacterium spp., Kocuria carniphila and Rhodococcus spp. were isolated only from the SBM-fed fish; whereas Brevibacterium and Enterococcus spp. were isolated only from the SBM- and IN-fed fish. Interestingly, Arthrobacter agillis, Kocuria carniphila and Rhodococcus spp. were adherent bacteria found only in the distal intestine of the $\mathrm{SBM}+\mathrm{OTC}$ group. The IN-fed fish lacked the presence of Pseudoalteromonas and Micrococcus spp., as well as several species of other genera identified in the other dietary groups. The numbers of isolated lactic acid species Marinilactibacillus psychrotolerans and Carnobacterium piscicola were higher in the digesta than adherent to the mucosa, and were higher in the FM-fed than in SBM- or IN-fed fish. Enterococcus spp., mostly Enterococcus faecalis, were not detected in the FM-fed fish, and their numbers were higher in the SBM- than IN-fed fish. In some cases, the total counts of viable bacteria were lower than the detection level when OTC was added to the diets (Table 4). Therefore, no adherent bacteria were identified from the mid intestine of fish fed the $\mathrm{FM}+$ OTC diet, the mid intestinal digesta of fish fed the IN + OTC diet, or from the distal intestinal digesta of fish fed the SBM + OTC and IN + OTC diets.

Table 5A. Log total viable counts (TVC) of identified bacterial species per gram mucosa (adherent) or digesta isolated from the mid and distal intestines of fish fed the fishmeal diets*

\begin{tabular}{|c|c|c|c|c|c|c|c|c|}
\hline & \multicolumn{4}{|c|}{ FM } & \multicolumn{4}{|c|}{$\mathrm{FM}+\mathrm{OTC}$} \\
\hline & \multicolumn{2}{|c|}{ Mid intestine } & \multicolumn{2}{|c|}{ Distal intestine } & \multicolumn{2}{|c|}{ Mid intestine } & \multicolumn{2}{|c|}{ Distal intestine } \\
\hline & Adherent & Digesta & Adherent & Digesta & Adherent & Digesta & Adherent & Digesta \\
\hline Log TVC & 3.63 & $5 \cdot 21$ & 3.92 & 4.83 & $<2 \cdot 0$ & 3.38 & 3.80 & 3.68 \\
\hline Number of isolates & 55 & 53 & 57 & 58 & 0 & 50 & 55 & 52 \\
\hline \multicolumn{9}{|l|}{ Bacterial genera/species } \\
\hline \multicolumn{9}{|l|}{ Gram-negatives } \\
\hline Acinetobacter spp. & $2 \cdot 26$ & 3.83 & $2 \cdot 62$ & 3.53 & ND & 1.94 & 2.51 & $2 \cdot 31$ \\
\hline A. johnsonii† & $2 \cdot 26$ & 3.53 & $2 \cdot 32$ & 3.05 & ND & ND & ND & ND \\
\hline Halomonas sp. $\dagger$ & 2.56 & 4.00 & 2.80 & 3.05 & ND & 1.94 & $2 \cdot 34$ & 2.53 \\
\hline Pseudoalteromonas spp. & 2.66 & 4.13 & ND & ND & ND & ND & ND & ND \\
\hline$P$. agarivorans $\dagger$ & 1.96 & 3.83 & ND & ND & ND & ND & ND & ND \\
\hline Pseudomonas spp. & 2.56 & 3.83 & 2.80 & 3.53 & ND & 1.94 & 2.64 & 1.83 \\
\hline Psychrobacter spp. & 2.56 & 3.83 & $2 \cdot 32$ & 3.35 & ND & 2.49 & $2 \cdot 64$ & $2 \cdot 31$ \\
\hline Psy. glacincolat & $2 \cdot 26$ & ND & ND & 3.05 & ND & ND & ND & ND \\
\hline Psy. submarinus $\dagger$ & $2 \cdot 26$ & 3.53 & ND & ND & ND & ND & ND & ND \\
\hline Unknown Gram-negative rodsł & 2.44 & 3.83 & 2.62 & 3.53 & ND & $2 \cdot 12$ & 2.34 & $2 \cdot 31$ \\
\hline \multicolumn{9}{|l|}{ Gram-positives } \\
\hline Bacillus spp. & 2.44 & 4.53 & $2 \cdot 80$ & $4 \cdot 13$ & ND & 2.34 & $2 \cdot 64$ & $2 \cdot 31$ \\
\hline B. badiust & ND & 3.53 & ND & 3.05 & ND & ND & ND & ND \\
\hline B. cereust & 1.96 & $4 \cdot 13$ & 2.32 & 3.53 & ND & ND & ND & ND \\
\hline B. sphaericus $\dagger$ & 1.96 & 3.83 & 2.32 & 3.35 & ND & ND & ND & ND \\
\hline Carnobacterium piscicola & 2.44 & 4.83 & $2 \cdot 62$ & 3.05 & ND & ND & ND & ND \\
\hline Jeotgalicoccus psychrophilus $\dagger$ & ND & ND & $2 \cdot 32$ & 3.35 & ND & $2 \cdot 25$ & 2.74 & 2.43 \\
\hline Marinilactibacillus psychrotolerans $\dagger$ & 2.86 & 4.23 & $2 \cdot 62$ & 4.00 & ND & ND & ND & ND \\
\hline Micrococcinae§ & ND & ND & 2.93 & ND & ND & $2 \cdot 25$ & 2.64 & 2.53 \\
\hline Micrococcus spp. & ND & ND & 2.62 & 3.05 & ND & ND & 2.64 & $2 \cdot 13$ \\
\hline Nocardia corynebacteroides $\dagger$ & 1.96 & 3.83 & $2 \cdot 80$ & ND & ND & ND & ND & ND \\
\hline Rathayibacter tritici $\dagger$ & 1.96 & ND & $3 \cdot 10$ & ND & ND & ND & ND & ND \\
\hline Staphylococcus spp. & ND & ND & 2.93 & 3.35 & ND & 2.34 & $2 \cdot 82$ & 2.43 \\
\hline Staph. equorum ssp. linens $\dagger$ & ND & ND & $2 \cdot 32$ & 3.05 & ND & $2 \cdot 25$ & 2.74 & $2 \cdot 31$ \\
\hline Staph. pasteuri† & ND & ND & 2.93 & ND & ND & ND & ND & ND \\
\hline Streptococcus spp. & $2 \cdot 26$ & 3.83 & 2.80 & 3.35 & ND & 2.12 & 2.34 & 2.43 \\
\hline Unknown Gram-positive coccil| & $2 \cdot 26$ & ND & $2 \cdot 32$ & 3.05 & ND & 1.94 & $2 \cdot 51$ & $2 \cdot 13$ \\
\hline Unknown & 2.44 & 4.13 & 3.02 & 3.65 & ND & 2.34 & 2.74 & 2.67 \\
\hline Yeast & 1.96 & 3.83 & $2 \cdot 62$ & 3.53 & ND & 1.94 & $2 \cdot 34$ & $2 \cdot 31$ \\
\hline Mould & + & & + & & & & & \\
\hline
\end{tabular}

FM, fishmeal; ND, not detected; OTC, oxytetracycline.

${ }^{*}$ For details of procedures, see p. 702.

†Partial sequence of 16S rRNA were analysed and edited in BioEdit; an initial BLAST-search in GenBank retrieved the taxonomic groups for which isolates showed highest identities.

$\ddagger$ Transparent pigmented colonies, died prior to positive identification.

$\S$ Unknown, died prior to positive identification.

|| Orange-pigmented colonies, died prior to positive identification 
Table 5B. Log total viable counts (TVC) of identified bacterial species per gram mucosa (adherent) or digesta isolated from the mid and distal intestines of fish fed the different experimental diets ${ }^{*}$

\begin{tabular}{|c|c|c|c|c|c|c|c|c|}
\hline & \multicolumn{4}{|c|}{ SBM } & \multicolumn{4}{|c|}{$\mathrm{SBM}+\mathrm{OTC}$} \\
\hline & \multicolumn{2}{|c|}{ Mid intestine } & \multicolumn{2}{|c|}{ Distal intestine } & \multicolumn{2}{|c|}{ Mid intestine } & \multicolumn{2}{|c|}{ Distal intestine } \\
\hline & Adherent & Digesta & Adherent & Digesta & Adherent & Digesta & Adherent & Digesta \\
\hline Log TVC & 3.99 & $5 \cdot 21$ & 4.41 & $5 \cdot 42$ & 2.99 & 3.43 & 3.59 & $<2 \cdot 0$ \\
\hline Number of isolates & 59 & 57 & 60 & 59 & 56 & 58 & 58 & 0 \\
\hline \multicolumn{9}{|l|}{ Bacterial genera/species } \\
\hline \multicolumn{9}{|l|}{ Gram-negatives } \\
\hline Acinetobacter spp. & $2 \cdot 76$ & 4.02 & $2 \cdot 62$ & $4 \cdot 33$ & $1 \cdot 16$ & 1.97 & ND & ND \\
\hline A. johnsonit & ND & 3.42 & ND & 3.93 & ND & ND & ND & ND \\
\hline Halomonas spp. $\dagger$ & $2 \cdot 76$ & $3 \cdot 72$ & ND & ND & 1.63 & $2 \cdot 27$ & $2 \cdot 79$ & ND \\
\hline Pseudoalteromonas spp. & ND & 3.42 & ND & ND & ND & ND & ND & ND \\
\hline Pseudomonas spp. & 2.58 & 4.02 & 3.47 & ND & ND & ND & ND & ND \\
\hline Psychrobacter sp. & 3.06 & $3 \cdot 72$ & 3.62 & 4.62 & 2.06 & ND & $2 \cdot 74$ & ND \\
\hline Psy. glacincola $†$ & $2 \cdot 76$ & 3.72 & $3 \cdot 22$ & 4.41 & 1.93 & ND & 2.44 & ND \\
\hline Psy. submarinus $\dagger$ & $2 \cdot 28$ & ND & ND & ND & ND & ND & ND & ND \\
\hline Vibrio spp. & 2.58 & 3.42 & $3 \cdot 10$ & $4 \cdot 10$ & ND & ND & ND & ND \\
\hline Unknown Gram-negative rodsł & 2.58 & 3.72 & $3 \cdot 10$ & 3.93 & 1.46 & $2 \cdot 15$ & 1.84 & ND \\
\hline \multicolumn{9}{|l|}{ Gram-positives } \\
\hline Arthrobacter agilis $\dagger$ & ND & ND & ND & ND & ND & ND & $2 \cdot 14$ & ND \\
\hline Bacillus spp. & $2 \cdot 28$ & 3.90 & ND & 4.23 & ND & $2 \cdot 15$ & $2 \cdot 62$ & ND \\
\hline Brachybacterium spp. $\dagger$ & $2 \cdot 28$ & 3.90 & ND & ND & 1.46 & $2 \cdot 27$ & ND & ND \\
\hline Brevibacterium spp. $\dagger$ & $2 \cdot 28$ & 3.42 & ND & ND & 1.46 & 1.97 & ND & ND \\
\hline Carnobacterium piscicola & 2.58 & 3.72 & $2 \cdot 62$ & 3.93 & ND & ND & ND & ND \\
\hline Enterococcus spp. & $2 \cdot 76$ & 4.02 & $3 \cdot 10$ & $4 \cdot 10$ & 1.46 & 2.45 & 1.84 & ND \\
\hline E. faecalis $\dagger$ & 2.58 & $3 \cdot 72$ & $2 \cdot 62$ & $4 \cdot 10$ & $1 \cdot 16$ & $2 \cdot 27$ & ND & ND \\
\hline Jeotgalicoccus psychrophilus $\dagger$ & 2.58 & ND & $2 \cdot 62$ & 3.93 & 1.63 & ND & ND & ND \\
\hline Kocuria carniphila† & ND & ND & ND & ND & ND & ND & $2 \cdot 14$ & ND \\
\hline Marinilactibacillus psychrotolerans $\dagger$ & $2 \cdot 58$ & $3 \cdot 72$ & ND & ND & $1 \cdot 16$ & ND & ND & ND \\
\hline Micrococcinae§ & 2.58 & 3.90 & $2 \cdot 92$ & 3.62 & 1.46 & ND & 2.44 & ND \\
\hline Micrococcus spp. & ND & 3.90 & $3 \cdot 10$ & 4.33 & ND & $2 \cdot 27$ & $2 \cdot 14$ & ND \\
\hline Rhodococcus spp. & ND & ND & ND & ND & ND & ND & $2 \cdot 32$ & ND \\
\hline Staphylococcus sp. & $3 \cdot 19$ & $4 \cdot 20$ & 3.62 & $4 \cdot 10$ & 2.06 & $2 \cdot 67$ & $2 \cdot 62$ & ND \\
\hline Staph. equorum ssp. linens $\dagger$ & 2.98 & $3 \cdot 72$ & $3 \cdot 22$ & ND & 1.85 & $2 \cdot 27$ & 2.54 & ND \\
\hline Staph. pasteuri† & ND & ND & 2.92 & 3.93 & 1.85 & $2 \cdot 27$ & 1.84 & ND \\
\hline Streptococcus spp. & ND & 3.72 & ND & ND & ND & $2 \cdot 15$ & 2.44 & ND \\
\hline Unknown Gram-positive coccill & 2.58 & 3.42 & 2.92 & $4 \cdot 10$ & 1.63 & 1.97 & $2 \cdot 32$ & ND \\
\hline Unknown & $2 \cdot 76$ & $3 \cdot 72$ & $2 \cdot 62$ & 3.93 & 1.46 & 1.67 & $2 \cdot 14$ & ND \\
\hline Yeast & $2 \cdot 76$ & $3 \cdot 72$ & 2.92 & 3.62 & ND & 1.97 & ND & ND \\
\hline Mould & + & & & & & & & \\
\hline
\end{tabular}

ND, not detected; OTC, oxytetracycline; SBM, soyabean meal.

${ }^{\star}$ For details of procedures, see p. 701.

†Partial sequence of $16 \mathrm{~S}$ rRNA were analysed and edited in BioEdit; an initial BLAST-search in GenBank retrieved the taxonomic groups for which isolates showed highest identities.

$\ddagger$ Transparent pigmented colonies, died prior to positive identification.

$\S$ Unknown, died prior to positive identification.

\| Orange-pigmented colonies, died prior to positive identification.

\section{Discussion}

The contribution of the intestinal microbiota to the pathological changes associated with SBM-induced enteritis in Atlantic salmon was investigated by calculating intestinal somatic indices, evaluating intestinal histology, the occurrence of HSP70 and caspase-3-positive cells, as well as PCNA-positive proliferative compartments at the base of the mucosal folds in the distal intestine, and characterizing the intestinal microbiota. The morphological characteristics of the inflamed distal intestine of the SBM-fed fish were in accordance with previous studies (van den Ingh et al. 1991, 1996; Baeverfjord \& Krogdahl, 1996; Nordrum et al. 2000; Hemre et al. 2005) and the inclusion of $3 \mathrm{~g}$ OTC/kg to the SBM diet did not influence the development of the inflammation, as reflected by the histological scores and the pathophysiological responses measured.

\section{Pathophysiological responses}

The longer PCNA-positive PCL in the distal intestine of SBMfed fish indicates a higher rate of cell renewal, likely a result of the inflammatory response (Wolf \& Dittrich, 1992). Sanden et al. (2005) reported a similar response to SBM in Atlantic salmon parr. A reduction in the number of mature, developed enterocytes would explain the dysfunction previously observed in this intestinal region (Bakke-McKellep et al. 2000; Nordrum et al. 2000; Krogdahl et al. 2003). Various plant lectins consumed with the diet have also been shown to increase crypt cell proliferation as well as cause morphological changes in the intestine of rats (Banwell et al. 1993; Pusztai et al. 1995), although soyabean lectin has been ruled out, at least as a sole cause of SBM-induced enteritis in salmon (van den Ingh et al. 1996). The increased number of apoptotic cells and reduced DISI in SBM-fed salmon both 
Table 5C. Log total viable counts (TVC) of identified bacterial species per gram mucosa (adherent) or digesta isolated from the mid and distal intestines of fish fed the different experimental diets*

\begin{tabular}{|c|c|c|c|c|c|c|c|c|}
\hline & \multicolumn{4}{|c|}{ IN } & \multicolumn{4}{|c|}{$\mathrm{IN}+\mathrm{OTC}$} \\
\hline & \multicolumn{2}{|c|}{ Mid intestine } & \multicolumn{2}{|c|}{ Distal intestine } & \multicolumn{2}{|c|}{ Mid intestine } & \multicolumn{2}{|c|}{ Distal intestine } \\
\hline & Adherent & Digesta & Adherent & Digesta & Adherent & Digesta & Adherent & Digesta \\
\hline Log TVC & 3.56 & $3 \cdot 61$ & 3.95 & 3.99 & $2 \cdot 90$ & $<2 \cdot 0$ & 3.02 & $<2 \cdot 0$ \\
\hline Number of isolates & 60 & 60 & 57 & 60 & 59 & 0 & 59 & 0 \\
\hline \multicolumn{9}{|l|}{ Bacterial genera/species } \\
\hline \multicolumn{9}{|l|}{ Gram-negatives } \\
\hline Acinetobacter spp. & $2 \cdot 00$ & 1.80 & $2 \cdot 80$ & ND & ND & ND & 1.53 & ND \\
\hline Halomonas sp. & 2.40 & 2.65 & $3 \cdot 20$ & 2.97 & 1.23 & ND & $2 \cdot 31$ & ND \\
\hline Pseudomonas sp. & 2.40 & 2.58 & $2 \cdot 90$ & $2 \cdot 79$ & ND & ND & ND & ND \\
\hline Psychrobacter sp. & $2 \cdot 18$ & $2 \cdot 40$ & $2 \cdot 68$ & $2 \cdot 89$ & 1.77 & ND & 1.93 & ND \\
\hline Psy. faecalis $\dagger$ & 1.70 & 2.50 & 2.50 & $2 \cdot 19$ & 1.83 & ND & 1.93 & ND \\
\hline Unknown Gram-negative rods $\ddagger$ & $2 \cdot 00$ & $2 \cdot 28$ & $2 \cdot 68$ & 2.49 & 1.53 & ND & 1.53 & ND \\
\hline \multicolumn{9}{|l|}{ Gram-positives } \\
\hline Bacillus spp. & 2.00 & ND & $2 \cdot 68$ & $2 \cdot 19$ & 1.23 & ND & ND & ND \\
\hline B. badiust & $1 \cdot 70$ & 1.80 & $2 \cdot 20$ & ND & ND & ND & ND & ND \\
\hline Brevibacterium sp.† & ND & 1.80 & ND & ND & ND & ND & ND & ND \\
\hline Carnobacterium piscicola & $2 \cdot 30$ & $2 \cdot 10$ & $2 \cdot 50$ & $2 \cdot 67$ & ND & ND & ND & ND \\
\hline Enterococcus faecalis $†$ & ND & ND & ND & $2 \cdot 19$ & 1.22 & ND & ND & ND \\
\hline Jeotgalicoccus psychrophilus $\dagger$ & $2 \cdot 60$ & 2.58 & $2 \cdot 80$ & $2 \cdot 67$ & 1.63 & ND & 1.23 & ND \\
\hline Marinilactibacillus psychrotolerans† & $2 \cdot 00$ & $2 \cdot 00$ & 3.00 & 3.00 & 0.93 & ND & 1.53 & ND \\
\hline Micrococcinae§ & 2.40 & $2 \cdot 40$ & $2 \cdot 20$ & 2.49 & 1.41 & ND & ND & ND \\
\hline Staphylococcus sp. & $2 \cdot 40$ & $2 \cdot 28$ & $2 \cdot 50$ & 3.09 & 1.77 & ND & $2 \cdot 23$ & ND \\
\hline Staph. equorum ssp. linens $\dagger$ & 2.54 & $2 \cdot 65$ & $2 \cdot 80$ & $2 \cdot 89$ & 1.63 & ND & $2 \cdot 34$ & ND \\
\hline Streptococcus sp. & $1 \cdot 70$ & $2 \cdot 28$ & $2 \cdot 90$ & 2.97 & 1.53 & ND & ND & ND \\
\hline Unknown Gram-positive coccill & $2 \cdot 18$ & $2 \cdot 10$ & $2 \cdot 20$ & 2.49 & 1.41 & ND & 1.71 & ND \\
\hline Unknown & $2 \cdot 18$ & $2 \cdot 10$ & $2 \cdot 68$ & 2.79 & 1.22 & ND & 1.53 & ND \\
\hline Yeast & $1 \cdot 70$ & ND & 2.50 & $2 \cdot 67$ & 1.41 & ND & 1.53 & ND \\
\hline Mould & + & & & & & & & \\
\hline
\end{tabular}

IN, inulin; ND, not detected; OTC, oxytetracycline.

${ }^{*}$ For details of procedures, see p. 701.

†Partial sequence of 16S rRNA were analysed and edited in BioEdit; an initial BLAST-search in GenBank retrieved the taxonomic groups for which isolates showed highest identities.

$\ddagger$ Transparent pigmented colonies, died prior to positive identification

$\S$ Unknown, died prior to positive identification.

|l Orange-pigmented colonies, died prior to positive identification.

suggest a concomitant loss of cells, explaining the significant shortening of mucosal folds observed by Baeverfjord \& Krogdahl (1996) and further reducing the number of functional enterocytes. The remaining cells also appear to be responding to the unidentified 'stressor(s)' in SBM by attempting to regulate the apoptotic pathway and facilitate cellular recovery, as the increased number of HSP70-positive cells indicates. Thus, the HSP70 are characterized by high inducibility during inflammation, representing an attempt by the cell to avoid apoptosis by an antagonizing effect of HSP70 on cell death pathways (Calderwood et al. 2005).

IN did not induce damage to the intestinal mucosa of the salmon as reported in Arctic charr (Olsen et al. 2001), although we did note a qualitative increase in the vacuolization of IN-fed fish. The contrasting findings in charr may be due to differing dietary levels of IN (twice the level of the current study) or differing analytic methods (transmission electron microscopy). Olsen et al. (2001) reported changes in the organization of microvilli and the presence of intracellular lamellar bodies in distal intestine enterocytes. Light microscopy does not allow sufficient resolution to evaluate these structures. However, Olsen et al. (2001) also reported increased vacuolization of distal intestine enterocytes (measured as percentage of cell volume). Therefore, the effect of IN, including possible beneficial effects, in Atlantic salmon diets merits further study.
The increased DISI in IN-fed fish appeared to be the result of hypertrophy of the muscularis externa. Greger (1999) reported similar hypertrophy of the caecal wall in rats fed IN, possibly caused by increased peristaltic activity.

The current study suggests that OTC inclusion results in a decrease in the rate of cellular proliferation in the distal intestinal proliferative compartments of Atlantic salmon. This is in accordance with the known action of tetracyclines, specifically inhibiting not only bacterial but also somatic cell mitochondrial protein synthesis. The resulting lack of oxidative ATP-generating capacity causes proliferation arrest of normal and malignant cells of epithelial origin (van den Bogert et al. 1986).

The digital image analysis employed to quantify the PCNApositive areas is presented here for the first time. Earlier methods of analysis in mice (Muskhelishvili et al. 2003) and fish (Ortego et al. 1994; Berntssen et al. 2001, 2004; Hemre et al. 2004; Sanden et al. 2005) differ significantly compared to the current study. The previous studies calculated proliferation indices (\% of total cells that stained positively for PCNA) either in a defined area, from a defined number of cells or along the entire cryptvillus length. A disadvantage of these types of measurements is that they are highly time consuming. Additionally, these methods do not consider the reduction in the height of villi (or mucosal folds), as observed in SBM-fed fish, a factor which may reduce the reliability of row counts as estimators of villus 
cell populations (Alison, 1995). The method used in the current study also allows measurement of areas in which individual cells cannot be discerned.

\section{Bacteriology}

Bacterial involvement in the pathogenesis cannot be excluded despite efforts to rule this out in the current study. Although OTC was effective in reducing bacterial numbers, in accordance with previous investigations in various fish species (Austin \& Al-Zahrani, 1988; Sugita et al. 1988; Kerry et al. 1997), the lack of effect on the inflammatory response suggests that: (1) microbiota had no influence on SBMinduced enteritis in salmon in the present study; (2) the concentration or activity of OTC was decreased by the time it reached the epithelium of the distal intestine so it could not sufficiently reduce numbers of potentially key adherent bacteria; (3) the alteration in the species composition of the microbial community was important (see later); and/or (4) the absence of microbiota in the digesta of the SBM + OTC-fed salmon may directly or indirectly have a similar detrimental effect on the intestine as the SBM. The second point may be substantiated by the absence of adherent bacteria in the more proximally located mid intestine versus the distal intestine of FM-fed fish treated with OTC. Physical properties of the digesta as influenced by feed ingredients, such as viscosity and $\mathrm{pH}$, may also have adversely influenced OTC's activity or ability to reach the epithelium. In future studies, inclusion of higher levels of OTC may therefore lead to a different result. Concerning the third point mentioned earlier, further investigation of the possible influence of Psychrobacter, Enterococcus, Micrococcus and Staphylococcus spp. in the pathogenesis of SBM-induced enteritis merits study since these were adherent bacteria in the distal intestine that were reduced but not eliminated by OTC. Futhermore, the role of other adherent bacteria present in the distal intestine of the SBM + OTC-fed group, but not in the SBM or other dietary groups, merit study as possible (facilitative) pathogens: Arthrobacter agillis, Kocuria carnophila and Rhodococcus spp. These may have been resistant to the OTC and/or their proliferation allowed by the suppressed population growth of other species, including those present in the digesta, caused by the addition of the antibiotic. Concerning the fourth point, the absence of microbiota in the digesta of not only the distal but also the mid intestine of the IN + OTC-fed fish did not result in histological changes. Most likely this rules out the possibility of any deficiency of microbially produced nutrients or metabolites as a potential cause of histological changes.

From the current study it is apparent that fish fed the SBM diet had an altered microbial population profile compared to FM- or IN-fed fish. By using soya agar (containing peptone from SBM) when culturing the bacteria we cannot rule out a certain selective effect that might have resulted in the larger diversity of the bacteria observed in the SBM-fed fish than in the other dietary groups. Nevertheless, the higher nitrogen-free extract fraction (indigestible carbohydrates) of the SBM-containing diets compared to FM, as well as soyabean's content of the non-digestible oligosaccharides stacchyose and raffinose may also have contributed to this. In single-stomached higher vertebrates, studies have shown that these components may result in a greater bacterial diversity (Konstantinov et al. 2003, 2004) and an increase in the number of bifidobacteria and/or lactobacilli (Ross et al. 1983; Jonnsson \& Hemmingsson, 1991; Okubo et al. 1994; Dongowski et al. 2002; Guo et al. 2004; Tzortzis et al. 2004). This latter finding, however, was not the case in the present study in which the highest levels of lactic acid bacteria were observed in the FM-fed salmon. The more diverse microbial community found in the SBM-fed salmon may also influence or be influenced by nutrient availability or utilization. Previous studies have repeatedly demonstrated lower macronutrient digestibilities when salmon are fed SBM (Olli et al. 1994; Olli \& Krogdahl 1995; Krogdahl et al. 2003). However, possible changes in levels of microbial metabolites - whether potentially beneficial, such as SCFA; or detrimental, such as ammonia, amines or amides - have not been studied.

Interestingly, the present results clearly showed that inclusion of $7.5 \%$ IN in the diet led to less diverse microbiota colonizing the gut. The present results are in accordance with a study on Arctic charr (Ring $\varnothing$ et al. 2006b) but contradict findings in mammals (Gibson \& Roberfroid, 1995; PoolZobel et al. 2002; $\mathrm{Xu}$ et al. 2002). The reason for this has not been elucidated, but we suggest that IN has a selective effect on Atlantic salmon and Arctic charr gastrointestinal microbiota. Whether this effect is also valid for other fish species and whether it has a beneficial or detrimental effect on fish health remains to be studied.

When evaluating the intestinal microbiota of fish, a major question arises: does the intestinal microbiota have any beneficial nutritive or health effect? During the last decade several investigations have attempted to evaluate whether the gut microbiota are able to inhibit growth of pathogenic bacteria in vitro (Gatesoupe, 1999; Ring $\varnothing$ et al. 2005). It is generally accepted that the gastrointestinal tract of fish is an important route of infection (Birkbeck \& Ring $\varnothing, 2005)$. Whether the dietary manipulations observed in the present study have any effect on colonization of pathogens in the gastrointestinal tract, or a protective effect in challenge studies, is not known, and these scientific challenges are worth investigating. Other studies of interest include the contribution of the gut microbiota to fish nutrition, nutrient availability and assimilation as well as their influence on nitrogen metabolism in the intestine of fish with the possibility of reducing ammonia excretion. In both cases, dietary manipulation and prebiotics may have beneficial effects as indicated by studies with higher vertebrates (see review by Bauer et al. 2006). The present study suggests that the significance of the gut microbiota in salmon, carnivorous animals heavily influenced by their seemingly inhospitable marine, cold-water environment, may be greater than previously assumed.

Long-term incubation under conditions conducive to those found in vivo in a marine poikilothermic organism, and identification based on a combination of various biochemical and physiological analyses as well as by sequencing 16S rRNA, showed that the Atlantic salmon gut is colonized by a diverse microbiota, many not previously isolated from the gastrointestinal tract of fish. Bacteria previously isolated include: Acinetobacter spp., Pseudoalteromonas spp., Pseudomonas spp., Vibrio spp., Bacillus spp., Carnobacterium piscicola, Micrococcus spp., Staphylococcus spp. and Streptococcus spp. (Cahill, 1990; Ringø et al. 1995; Hansen \& Olafsen, 1999; Ring $\varnothing$ \& Birkbeck, 1999; Ring \& \& Olsen, 1999). 
The following Gram-negative bacteria have not been isolated previously: Acinetobacter johnsonii, Halomonas spp., Pseudoalteromonas agarivorans, Psychrobacter spp., Psychrobacter faecalis, Psychrobacter glacincola and Psychrobacter submarinus. Nor have the Gram-positive bacteria Arthrobacter agilis, Jeotgalicoccus psychrophilus, Marinilactibacillus psychrotolerans, Nocardia corynebacteroides, Rathayibacter tritici, Rhodococcus spp., Staphylococcus equorum ssp. linens and Staphylococcus pasteuri. Earlier reviews by Cahill (1990), Ring $\varnothing$ et al. (1995) and Ring $\varnothing$ \& Birkbeck (1999) suggested that the gastrointestinal tract microbiota of fish is simpler than that of endothermic animals. However, the present study demonstrates that this statement may need some revision.

The findings of Ring $\varnothing$ et al. (2006b) and our present findings from Atlantic salmon indicate that Halomonas spp. belong to the adherent microbiota in fish and the present observation is therefore a contribution to the knowledge of the microbiota of the fish digestive tract. Recently, information has become available showing the presence of different Psychrobacter species in samples from the distal intestine of Arctic charr (Ring $\varnothing$ et al. 2006b), the alimentary tract of Atlantic salmon (Ringø et al. 2006a; the present study), sterile rehydrated salt-cured and dried salt-cured cod (Bjørkevoll et al. 2003), the Okhotsk Sea (Yumoto et al. 2003) and from deep-sea sediments (Zeng et al. 2004).

The Gram-positive, catalase-negative, non-sporulating and motile marine lactic acid bacteria Marinilactibacillus psychrotolerans was first isolated and described by Ishikawa et al. (2003) from living and decomposing marine organisms collected from the temperate and subtropical areas of Japan. Later M. psychrotolerans has been isolated from red-smear soft cheeses (Maoz et al. 2003) and deep-sea sediments of the Nankai Trough (Toffin et al. 2004) as well as the digestive tract of Atlantic salmon (E Ring $\varnothing$, unpublished results; the present study). This information indicates that this lactic acid bacterium is well adapted to different ecological habitats. The first description of Staphylococcus pasteuri was by Chesneau et al. (1993), who isolated it from human, animal and food specimens. $S$. pasteuri seems to be well adapted to a wide range of ecological niches as well, since it has been isolated both from stratospheric air samples at $41 \mathrm{~km}$ (Wainwright et al. 2003) and in the distal intestine of fish fed FM and SBM (the present study).

In conclusion, the involvement of gut microbiota on the pathogenesis of a diet-related mucosal disorder in the teleost Atlantic salmon, SBM-induced enteritis, was not ameliorated by adding the broad-spectrum antibiotic OTC to the diet at $3 \mathrm{~g} \mathrm{OTC} / \mathrm{kg}$ diet. In the distal intestinal mucosa of both SBM and SBM + OTC-fed fish, a significant increase in the PCL as well as apparent increases in the number of cells undergoing cellular repair processes and apoptosis were observed as pathophysiological responses related to the inflammation. However, SBM inclusion in the diet appeared to increase the number and diversity of the microbial community, whereas IN reduced diversity. The implications of the present findings to the intestine's as well as fishes' nutrition and health remain to be elucidated. Further study on the influence of the gastrointestinal microbiota on fish health merit investigation as the global production of fish increases.

\section{Acknowledgements}

The authors acknowledge the skilful technical assistance of Birgit Røe for processing of the intestinal tissue, Inger Rudshaug and Laila Aune for excellent work with the immunohistochemistry, and Gjermund Gunnes for expert assistance with the digital image analysis, all at the Norwegian School of Veterinary Science. We are grateful to Suiker Unie for supplying inulin. Financial support for the study was provided by the Research Council of Norway and the Norwegian School of Veterinary Science via the CoE Aquaculture Protein Centre (project number 145949/120).

\section{References}

Alison MR (1995) Assessing cellular proliferation: what's worth measuring? Hum Exp Toxicol 14, 935-944.

Austin B \& Al-Zahrani AMJ (1988) The effect of antimicrobial compounds on the gastrointestinal microflora of rainbow trout, Salmo gairdneri Richardson. J Fish Biol 33, 1-14.

Austreng E, Storebakken T \& Åsgård T (1987) Growth rate estimates for cultured Atlantic salmon and rainbow trout. Aquaculture 60 , $157-160$.

Baeverfjord G \& Krogdahl Å (1996) Development and regression of soybean meal induced enteritis in Atlantic salmon, Salmo salar L., distal intestine: a comparison with the intestines of fasted fish. J Fish Dis 19, 375-387.

Bakke-McKellep AM, Press CM, Baeverfjord G, Krogdahl ^ \& Landsverk T (2000) Changes in immune and enzyme histochemical phenotypes of cells in the intestinal mucosa of Atlantic salmon, Salmo salar L., with soybean meal-induced enteritis. J Fish Dis 23, 115-127.

Banwell JG, Howard R, Adrian TE, Diamond RH \& Abramowsky C (1993) Small intestinal growth caused by feeding red kidney bean phytohemagglutinin lectin to rats. Gastroenterology 104, 1669-1677.

Bauer E, Williams BA, Smidt H, Mosenthin R \& Verstegen MWA (2006) Influence of dietary components on development of the microbiota in single-stomached species. Nutr Res Rev 19, 63-78.

Berntssen MHG, Aspholm OO, Hylland K, Wendelaar Bonga SE \& Lundebye AK (2001) Tissue metallothionein, apoptosis and cell proliferation responses in Atlantic salmon (Salmo salar L.) parr fed elevated dietary cadmium. Comp Biochem Physiol C Toxicol Pharmacol 128, 299-310.

Berntssen MHG, Hylland K, Julshamn K, Lundebye AK \& Waagbo R (2004) Maximum limits of organic and inorganic mercury in fish feed. Aquacult Nutr 10, 83-97.

Birkbeck TH \& Ring $\varnothing$ E (2005) Pathogenesis and the gastrointestinal tract of growing fish. In Microbial Ecology in Growing Animals, pp. 208-234 [W Holzapfel \& P Naughton, editors]. Biology in Growing Animals Series [SG Pierzynowski \& R Zabielski, editors]. Edinburgh: Elsevier.

Bjørkevoll I, Olsen RL \& Skjerdal OT (2003) Origin and spoilage potential of the microbiota dominating genus Psychrobacter in sterile rehydrated salt-cured and dried salt-cured cod (Gadus morhua). Int J Food Microbiol 84, 175-187.

Buttle LG, Burrells AC, Good JE, Williams PD, Southgate PJ \& Burrells C (2001) The binding of soybean agglutinin (SBA) to the intestinal epithelium of Atlantic salmon, Salmo salar and Rainbow trout, Oncorhynchus mykiss, fed high levels of soybean meal. Vet Immunol Immunopathol 80, 237-244.

Cahill MM (1990) Bacterial flora of fishes: a review. Microb Ecol 19, 21-41.

Calderwood SK, Theriault JR \& Gong J (2005) Message in a bottle: role of the $70-\mathrm{kDa}$ heat shock protein family in anti-tumor immunity. Eur J Immunol 35, 2518-2527. 
Chehade M \& Mayer L (2005) Oral tolerance and its relation to food hypersensitivities. J Allergy Clin Immunol 115, 3-12.

Chesneau O, Morvan A, Grimont F, Labischinski H \& Elson N (1993) Staphylococcus pasteuri sp. nov., isolated from human, animal and food specimens. Int J Syst Bacteriol 43, 237-244.

Dongowski G, Huth M, Gebhardt E \& Flamme W (2002) Dietary fiber-rich barley products beneficially affect the intestinal tract of rats. J Nutr 132, 3704-3714.

Fenoglio-Preiser CM, Noffsinger AE, Stemmermann GN, Lantz PE, Lindstrom MB \& Rilke FO (1999) Inflammatory bowel disease. In Gastrointestinal Pathology: An Atlas and Text, 2nd ed. pp. 631-716 [CM Fenoglio-Preiser, editor]. Philadelphia, PA: Lippincott-Raven Publishers.

Flickinger EA, Van Loo J \& Fahey C Jr (2003) Nutritional responses to the presence of inulin and oligofructose in the diets of domesticated animals: a review. Crit Rev Food Sci 43, 19-60.

Gatesoupe FJ (1999) The use of probiotics in aquaculture. Aquaculture 180, 147-165.

Gibson GR \& Roberfroid MB (1995) Dietary modulation of the human colonic microbiota: introducing the concept of prebiotics. J Nutr 125, 1401-1412.

Greger JL (1999) Nondigestible carbohydrates and mineral bioavailability. J Nutr 129, Suppl., 1434S-1435S.

Grittenden RG \& Playne MJ (1996) Production, properties and applications of food-grade oligosaccharides. Trends Food Sci Technol 7, $353-361$.

Guo FC, Williams BA, Kwakkel RP, Li HS, Li XP, Luo JY, Li WK \& Verstegen MWA (2004) Effects of mushroom and herb polysaccharides, as alternatives for an antibiotic, on the cecal microbial ecosystem in broiler chickens. Poult Sci 83, 175-182.

Hanauer SB (2004) Update on the etiology, pathogenesis and diagnosis of ulcerative colitis. Nat Clin Pract Gastroenterol 1, 26-31.

Hansen GH \& Olafsen JA (1999) Bacterial interactions in early life stages of marine cold water fish. Microb Ecol 38, 1-26.

Heikkinen J, Vielma J, Kemiläinen O, Tiirola M, Eskelinen P, Kiuru T, Navia-Paldanius D \& von Wright (2006) Effects of soybean meal based diet on growth performance, gut histopathology and intestinal microbiota of juvenile rainbow trout (Oncorhynchus mykiss). Aquaculture 261, 259-268.

Hemre GI, Deng DF, Wilson RP \& Berntssen MHG (2004) Vitamin A metabolism and early biological responses in juvenile sunshine bass (Morone chrysops $\times$ M. saxatilis) fed graded levels of vitamin A. Aquaculture 234, 645-658.

Hemre GI, Sanden M, Bakke-McKellep AM, Sagstad A \& Krogdahl A (2005) Growth, feed utilization and health of Atlantic salmon Salmo salar L. fed genetically modified compared to non-modified commercial hybrid soybeans. Aquacult Nutr 11, 157-167.

Hooper LV \& Gordon JI (2001) Commensal host-bacteria relationships in the gut. Science 229, 1115-1118.

Ishikawa M, Nakajima K, Yanagi M, Yamamota Y \& Yamasato K (2003) Marinilactibacillus psychrotolerans gen. nov., sp. nov., a halophilic and alkaliphilic marine lactic acid bacterium isolated from marine organisms in temperate and subtropical areas of Japan. Int J Syst Evol Microbiol 53, 711-720.

Jenkins DJA, Kendal CWC \& Vuksan V (1999) Inulin, oligofructose and intestinal function. J Nutr 129, Suppl., 1431S-1433S.

Jonnsson E \& Hemmingsson S (1991) Establishment in the piglet gut of lactobacilli capable of degrading mixed-link beta-glucans. J Appl Bacteriol 70, 512-516.

Kerry J, NicGabhainn S \& Smith P (1997) Changes in oxytetracycline resistance of intestinal microflora following oral administration of this agent to Atlantic salmon (Salmo salar L.) smolts in a marine environment. Aquaculture 157, 187-195.

Konstantinov SR, Favier CF, Zhu WY, Williams BA, Klüss J, Souffrant WB, De Vos WM, Akkermans ADL \& Smidt H (2004) Microbial diversity studies of the porcine gastrointestinal ecosystem during weaning transition. Anim Res 53, 317-324.
Konstantinov SR, Zhu WY, Williams BA, Tamminga S, De Vos WM \& Akkermans ADL (2003) Effect of fermentable carbohydrates on piglet faecal bacterial communities as revealed by denaturing gradient gel electrophoresis analysis of $16 \mathrm{~S}$ ribosomal DNA. FEMS Microbiol Ecol 43, 225-235.

Krogdahl A, Bakke-McKellep AM \& Baeverfjord G (2003) Effects of graded levels of standard soybean meal on intestinal structure, mucosal enzyme activities, and pancreatic response in Atlantic salmon (Salmo salar L.). Aquacult Nutr 9, 361-371.

Krogdahl A, Bakke-McKellep AM, Røed KH \& Baeverfjord G (2000) Feeding Atlantic salmon Salmo salar L. soybean products: effects on disease resistance (furunculosis), and lysozyme and IgM levels in the intestinal mucosa. Aquacult Nutr 6, 77-84.

Maoz A, Mayr R \& Scherer S (2003) Temporal stability and biodiversity of two complex antilisterial cheese ripening microbial consortia. Appl Environ Microbiol 69, 4012-4018.

Muskhelishvili L, Latendresse JR, Kodell RL \& Henderson EB (2003) Evaluation of cell proliferation in rat tissues with BrdU, PCNA, Ki-67(MIB-5) immunohistochemistry and in situ hybridization for histone mRNA. J Histochem Cytochem 51, 1681-1688.

Nordrum S, Bakke-McKellep AM, Krogdahl A \& Buddington RK (2000) Effects of soybean meal and salinity on intestinal transport of nutrients in Atlantic salmon (Salmo salar L.) and rainbow trout (Oncorhynchus mykiss). Comp Biochem Physiol B Biochem Mol Biol 125, 317-335.

Okubo $\mathrm{T}$, Ishihara $\mathrm{N}$, Takahash $\mathrm{H}$, Fujisawa $\mathrm{T}$, Kim M, Yamamoto T \& Misuoka T (1994) Effects of partially hydrolysed guar gum intake in human intestinal microflora and its metabolism. Biosci Biotechnol Biochem 58, 1364-1369.

Olli JJ \& Krogdahl A (1995) Alcohol soluble components of soybeans seem to reduce digestibility in fish-meal-based diets for Atlantic salmon, Salmo salar L. Aquacult Res 26, 831-835.

Olli JJ, Krogdahl Å, van den Ingh TSGA \& Brattås LE (1994) Nutritive value of four soybean products in diets for Atlantic salmon (Salmo salar, L.). Acta Agric Scand 44, 50-60.

Olsen RE, Myklebust R, Kryvi H, Mayhew TM \& Ring $\varnothing$ E (2001) Damaging effect of dietary inulin on intestinal enterocytes in Arctic char (Salvelinus alpinus L.). Aquacult Res 32, 931-934.

Ortego LS, Hawkins WE, Walker WW, Krol RM \& Benson WH (1994) Detection of proliferating cell nuclear antigen in tissues of 3 small fish species. Biotech Histochem 69, 317-323.

Pitcher DG, Saunders NA \& Owens RJ (1989) Rapid extraction of bacterial genomic DNA with guanidum thiocynate. Lett Appl Microbiol 8, 151-156.

Pool-Zobel B, Van Loo J, Rowland I \& Roberfroid MB (2002) Experimental evidence on the potential of prebiotic fructans to reduce the risk of colon cancer. Br J Nutr 87, 273-281.

Pusztai A, Ewen SWB, Grant G, Peumans WJ, van Damme EJM, Coates ME \& Bardocz S (1995) Lectins and also bacteria modify the glycosylation of gut surface receptors in the rat. Glycoconjugate $J$ 12, 22-35.

Ring $\varnothing \mathrm{E}(1993)$ The effect of chromic oxide $\left(\mathrm{Cr}_{2} \mathrm{O}_{3}\right)$ on aerobic bacterial populations associated with the epithelial mucosa of Arctic charr, Salvelinus alpinus (L.). Can J Microbiol 39, 1169-1173.

Ring $\varnothing$ E \& Birkbeck TH (1999) Intestinal microflora of fish larvae and fry. Aquacult Res 30, 73-93.

Ring $\varnothing$ E \& Olsen RE (1999) The effect of diet on aerobic bacterial flora associated with intestine of Arctic charr (Salvelinus alpinus L.). J Appl Microbiol 86, 22-28.

Ring $\varnothing$ E, Schillinger U \& Holzapfel W (2005) Antimicrobial activity of lactic acid bacteria isolated from aquatic animals and the use of lactic acid bacteria in aquaculture. In Microbial Ecology in Growing Animals, pp. 418-453 [W Holzapfel \& P Naughton, editors]. Biology in Growing Animals Series [SG Pierzynowski \& R Zabielski, editors]. Edinburgh: Elsevier.

Ring $\varnothing$ E, Sperstad S, Myklebust R, Mayhew TM, Mjelde A, Melle W \& Olsen RE (2006a) The effect of dietary krill 
supplementation on epithelium-associated bacteria in the hindgut of Atlantic salmon (Salmo salar L.). A microbial and electron microscopical study. Aquacult Res 37, 1644-1653.

Ring $\varnothing$ E, Sperstad S, Myklebust R, Mayhew TM \& Olsen RE (2006b) The effect of dietary inulin on the aerobic bacteria associated with hindgut of Arctic charr (Salvelinus alpinus L.). Aquacult Res 37, 891-897.

Ring $\varnothing$ E, Sperstad S, Myklebust R, Refstie S \& Krogdahl A (2006c) Characterisation of the gut microbiota associated with intestine of Atlantic cod (Gadus morhua L.). The effect of fish meal, standard soybean meal and a bioprocessed soybean meal. Aquaculture 261, $829-841$.

Ring $\varnothing$ E, Strøm E \& Tabachek JA (1995) Intestinal microflora of salmonids: a review. Aquacult Res 26, 773-789.

Roberfroid MB (2002) Functional food concept and its application to prebiotics. Digest Liver Dis 34, 105-110.

Roberfroid MB, Van Loo JA \& Gibson GR (1998) The bifidogenic nature of chicory inulin and its hydrolysis products. J Nutr 128, $11-19$.

Ross AH, Eastwood MA, Brydon WG, Anderson JR \& Anderson DM (1983) A study of the effects of dietary gum Arabic in humans. Am J Clin Nutr 37, 368-375.

Rumsey GL, Siwicki AK, Anderson DP \& Bowser PR (1994) Effect of soybean protein on serological response, non-specific defense mechanisms, growth, and protein utilization in rainbow trout. Vet Immunol Immunopathol 41, 323-339.

Sanden M, Berntssen MHG, Krogdahl Å, Hemre GI \& Bakke-McKellep AM (2005) An examination of the intestinal tract of Atlantic salmon (Salmo salar L.) parr fed different varieties of soy and maize. J Fish Dis 28, 317-330.

Sugita H, Fukumoto M, Koyama H \& Deguchi Y (1988) Changes in the fecal microflora of goldfish Carassius auratus with the oral administration of oxytetracycline. Nippon Suisan Gakk 54, 2181-2187.

Toffin L, Webster G, Weightman AJ, Fry JC \& Prieur D (2004) Molecular monitoring of culturable bacteria from deep-sea sediment of the Nankai Trough, Leg 190 Ocean Drilling Program. FEMS Microbiol Ecol 48, 357-367.
Tzortzis G, Goulas AK, Baillon M-LA, Gibson GR \& Rastall RA (2004) In vitro evaluation of the fermentation properties of galactooligosaccharides synthesised by $\alpha$-galactosidase from Lactobacillus reuteri. Appl Microbiol Biotechnol 64 106-111.

van den Bogert C, van Kernebeek G, de Leij L \& Kroon AM (1986) Inhibition of mitochondrial protein synthesis leads to proliferation arrest in the G1-phase of the cell cycle. Cancer Lett 32, 41-51.

van den Ingh TSGA \& Krogdahl A (1990) Negative effects of antinutritional factors from soya beans in salmonids. Tijdschr Diergeneesk 115, 935-938.

van den Ingh TSGA, Krogdahl Å, Olli JJ, Hendriks HGCJ \& Koninkx JGJF (1991) Effects of soybean-containing diets on the proximal and distal intestine in Atlantic salmon (Salmo salar): a morphological study. Aquaculture 94, 297-305.

van den Ingh TSGA, Olli JJ \& Krogdahl Å (1996) Alcohol-soluble components in soybeans cause morphological changes in the distal intestine of Atlantic salmon, Salmo salar L. J Fish Dis 19, $47-53$.

Wainwright M, Wickramasinghe NC, Narlikar JV \& Rajaratnam P (2003) Microorganisms cultured from stratospheric air samples obtained at $41 \mathrm{~km}$. FEMS Microbiol Lett 218, 161-165.

Wolf HK \& Dittrich KL (1992) Detection of proliferating cell nuclear antigen in diagnostic histopathology. J Histochem Cytochem $\mathbf{4 0}$, $1269-1273$.

Xu ZR, Zou XT, Hu CH, Xia MS, Zhan XA \& Wang MQ (2002) Effects of dietary fructooligosaccharides on digestive enzyme activities, intestinal microflora and morphology of growing pigs. Asian Austral J Anim Sci 15, 1784-1789.

Yumoto I, Hirota K, Sogabe Y, Nodasaka Y, Yokota Y \& Hoshino T (2003) Psychrobacter okhotskensis sp. nov., a lipase producing facultative psychrophile isolated from the coast of the Okhotsk Sea. Int J Syst Evol Microbiol 53, 1985-1989.

Zeng X, Xiao X, Wang P \& Wang FP (2004) Screening and characterization of psychrotrophic lipolytic bacteria from deep-sea sediments. J Microbiol Biotechnol 14, 952-958. 